PNNL-11401

UC-721

\title{
Organic Tank Safety Project: Effect of Water Partial Pressure on the Equilibrium Water Content of Waste Samples from Hanford Tank 241-BY-108
}

R. D. Scheele

P. R. Bredt

R. L. Sell

February 1997

Prepared for the U.S. Department of Energy under Contract DE-AC06-76RLO 1830

Pacific Northwest National Laboratory

Richland, Washington 99352

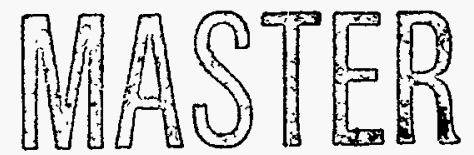





\section{DISCLAIMER}

Portions of this document may be illegible in electronic image products. Images are produced from the best available original document. 


\section{Summary}

Water content plays a crucial role in the strategy developed by Webb et al. (1995) to prevent propagating or sustainable chemical reactions in the organic-bearing wastes stored in the 20 Organic Tank Watch List tanks at the U. S. Department of Energy's Hanford Site. Because of water's importance in ensuring that the organic-bearing wastes continue to be stored safely, Duke Engineering and Services Hanford commissioned the Pacific Northwest National Laboratory (PNNL) to investigate the effect of water partial pressure $\left(\mathrm{P}_{\mathrm{H} 2 \mathrm{O}}\right)$ on the water content of organic-bearing or representative wastes. Of the various interrelated controlling factors affecting the water content in wastes, $\mathrm{P}_{\mathrm{H} 2 \mathrm{O}}$ is the most susceptible to being controlled by the arid Hanford Site's environmental conditions and, if necessary, could be managed to maintain the water content at an acceptable level or could be used to adjust the water content back to an acceptable level.

Of the various waste types resulting from weapons production and waste-management operations at the Hanford Site, Webb et al. (1995) determined that saltcake wastes are the most likely to require active management to maintain the wastes in a Conditionally Safe condition. A Conditionally Safe waste is one that satisfies the waste classification criteria based on water content alone or a combination of water content and either total organic carbon (TOC) content or waste energetics. To provide information on the behavior of saltcake wastes, two waste samples taken from Tank 241-BY-108 (BY-108) were selected for study, even though BY-108 is not on the Organic Tanks Watch List, because of their ready availability and their similarity to some of the organic-bearing saltcakes.

In these BY-108 studies, PNNL exposed waste obtained by Core 99 from the uppermost 5-cmsegment sample (Segment 1) and from the lower quarter portion of the next 48-cm-segment sample (Subsegment 2D) to water partial pressures of $2.2,7.6,18,27$, and 29 torr at $30^{\circ} \mathrm{C}$, the nominal temperature of the uppermost waste in BY-108. These water partial pressures encompass the minimum $P_{\mathrm{H} 2 \mathrm{O}}$ observed at the Hanford Site between 1985 and 1995 and the higher water partial pressures that may exist in the tank. The water content was monitored until stabilized or appeared to be approaching a stable level, at which time the samples exposed to 2.2 and 29 torr were switched to determine whether hydration and dehydration had an effect on the retentive capabilities of these wastes and whether the samples had achieved a true equilibrium water content. The water contents were determined gravimetrically by drying in a $105^{\circ} \mathrm{C}$ oven until a stable mass was reached.

Our studies indicate that, as expected, the equilibrium water content of these saltcake wastes depends on the $\mathrm{P}_{\mathrm{H} 2 \mathrm{O}}$. Exposure to water partial pressures ranging from 2.2 to 29 torr resulted in water contents in the homogenized Segment 1 sample ranging from 1 to $48 \mathrm{wt} \%$ water, respectively. Exposure of homogenized Subsegment 2D to water partial pressures ranging from 2.2 to 29 torr resulted in water contents ranging from 1 to $62 \mathrm{wt} \%$ water.

The differences between the two BY-108 waste samples taken by the same core sampling within $48 \mathrm{~cm}$ of each other indicate that water contents of different saltcake wastes depend on their chemical compositions. Segment 1 sorbs higher amounts of water at water partial pressures $<20$ torr; however, above 20 torr of water, Subsegment 2D sorbs higher amounts of water than Segment 1 . These differences 
in behavior are likely due to the higher phosphate and aluminum contents in Segment 1 and the higher nitrate concentration in Subsegment 2D. Nitrate behavior has been studied; however, the behavior of phosphate and aluminum either have not been studied, or the study yielded confounded results.

The results of these studies also indicate that if the uppermost waste in BY-108 and the waste within another $48 \mathrm{~cm}$ are allowed to equilibrate with the ambient Hanford water partial pressures ranging from monthly averages of 3.5 to 8 torr at current waste temperatures (about $30^{\circ} \mathrm{C}$ ), their water contents will range from 1 to $16 \mathrm{wt} \%$ and between 3 and $4 \mathrm{wt} \%$, respectively. These water contents are less than the $20 \mathrm{wt} \%$ water content guaranteeing that an organic-bearing waste will not support a propagating reaction (Webb et al. 1995). Thus it will be necessary to rely on the combined moisture and TOC or energetics criteria to ensure that the wastes are Conditionally Safe. At the average Hanford $\mathrm{P}_{\mathrm{H} 2 \mathrm{O}}$ of 5.5 torr, based on interpolation, the equilibrium water content of the uppermost $50 \mathrm{~cm}$ in BY-108 will be about $9 \mathrm{wt} \%$ water, assuming that Segment 1 is representative of this layer.

The observed reversibility of the water loss/gain displayed by both samples shows that water content in these wastes can be controlled by controlling the $\mathrm{P}_{\mathrm{H} 2 \mathrm{O}}$ in the tank's headspace. This indicates that it may be possible to rehydrate organic-bearing saltcake wastes using air with a controlled $\mathrm{P}_{\mathrm{H} 2 \mathrm{O}}$. 


\section{Acknowledgments}

We thank the following people for their invaluable support in developing a method for measuring the equilibrium water content of Hanford wastes and for helping with this report: L. L. Burger was our scientific sounding board, consultant, and reviewer as we attempted to understand the behavior of the different materials as they were exposed to water vapor; $\mathrm{K}$. W. Burke provided the Hanford Site environmental water partial pressures; C. D. Carlson provided a technical peer review of the document; W. C. Cosby provided editorial review and assistance in publishing this report; Duke Engineering and Services Hanford, Inc. and the U.S. Department of Energy provided funding for the project.

Pacific Northwest National Laboratory is operated for the U.S. Department of Energy by Battelle under Contract DE-AC06-76RLO 1830. 



\section{Glossạry}

$\begin{array}{ll}\text { DTA } & \text { differential thermal analyzer } \\ \text { DTG } & \text { differential TGA } \\ \text { GEA } & \text { gamma energy analysis } \\ \text { HLW } & \text { high-level waste } \\ \text { IC } & \text { ion chromatography } \\ \text { ICP/AES } & \text { inductively coupled argon plasma/atomic emission spectroscopy } \\ \text { ML } & \text { mega liters } \\ \text { PH2O } & \text { water partial pressure } \\ \text { PNNL } & \text { Pacific Northwest National Laboratory } \\ \text { PUREX } & \text { plutonium uranium reduction and extraction (plant) } \\ \text { RPD } & \text { relative percent difference } \\ \text { TGA } & \text { thermogravimetric analysis } \\ \text { TIC } & \text { total inorganic carbon } \\ \text { TOC } & \text { total organic carbon } \\ \text { WHC } & \text { Westinghouse Hanford Company } \\ & \end{array}$





\section{Contents}

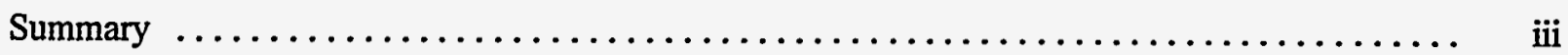

Acknowledgments $\ldots \ldots \ldots \ldots \ldots \ldots \ldots \ldots \ldots \ldots \ldots \ldots \ldots \ldots \ldots \ldots \ldots \ldots \ldots \ldots \ldots \ldots$

Glossary $\ldots \ldots \ldots \ldots \ldots \ldots \ldots \ldots \ldots \ldots \ldots \ldots \ldots \ldots \ldots \ldots \ldots \ldots \ldots \ldots \ldots \ldots \ldots \ldots \ldots$ vii

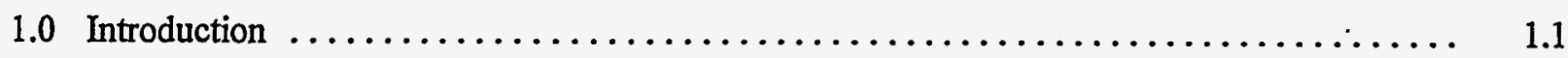

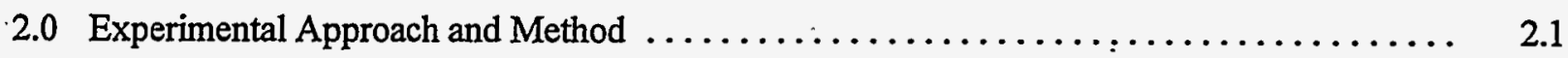

3.0 BY-108 Fill History, Temperatures, and Sample Composition $\ldots \ldots \ldots \ldots \ldots \ldots \ldots \ldots . .1$

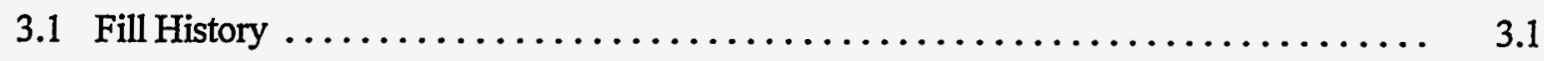

3.2 Temperature History $\ldots \ldots \ldots \ldots \ldots \ldots \ldots \ldots \ldots \ldots \ldots \ldots \ldots \ldots \ldots \ldots \ldots \ldots \ldots \ldots \ldots .2$

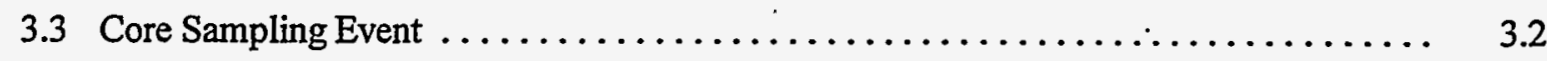

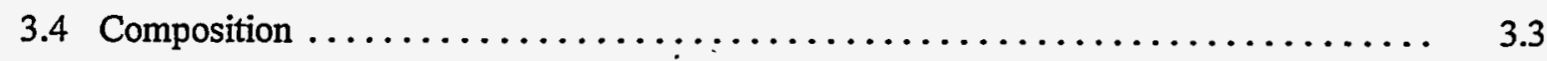

4.0 Water Retention of $B Y-108$ Waste $\ldots \ldots \ldots \ldots \ldots \ldots \ldots \ldots \ldots \ldots \ldots \ldots \ldots \ldots \ldots \ldots \ldots \ldots \ldots \ldots$

4.1 Water Content Versus Time $\ldots \ldots \ldots \ldots \ldots \ldots \ldots \ldots \ldots \ldots \ldots \ldots \ldots \ldots \ldots \ldots \ldots \ldots \ldots \ldots \ldots$

4.1.1 Behavior of Segment 1 Waste $\ldots \ldots \ldots \ldots \ldots \ldots \ldots \ldots \ldots \ldots \ldots \ldots \ldots \ldots \ldots \ldots \ldots \ldots, 4$

4.1.2 Behavior of Subsegment 2D Waste $\ldots \ldots \ldots \ldots \ldots \ldots \ldots \ldots \ldots \ldots \ldots \ldots \ldots \ldots \ldots$

4.2 Effect of $\mathrm{P}_{\mathrm{H} 20}$ on Equilibrium Water Content $\ldots \ldots \ldots \ldots \ldots \ldots \ldots \ldots \ldots \ldots \ldots \ldots \ldots$

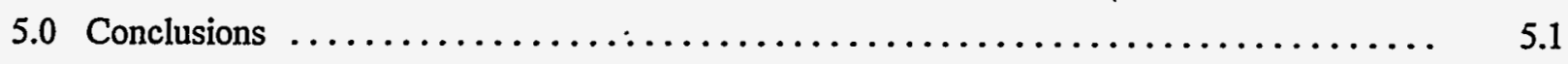

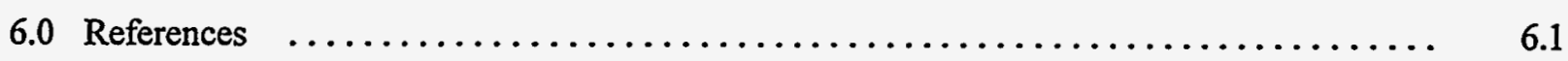




\section{Figures}

1.1 Average Hanford Monthly $\mathrm{P}_{\mathrm{H} 2 \mathrm{O}} 1980-1995 \ldots \ldots \ldots \ldots \ldots \ldots \ldots \ldots \ldots \ldots \ldots \ldots \ldots \ldots \ldots \ldots$

2.1 Schematic of Constant Humidity Chambers Used for Testing $\ldots \ldots \ldots \ldots \ldots \ldots \ldots \ldots .1$

4.1 Effect of Exposure Time to Selected Partial Pressures of Water at $30^{\circ} \mathrm{C}$ on the Water Content of Waste Samples Obtained by Core 99 Segment 1 from BY-108 . . . . . . . .

4.2 Thermal Behavior as Measured by TGA and DTA of Segment 1 Waste after Equilibrating with a $\mathrm{P}_{\mathrm{H} 2 \mathrm{O}}$ of 2.2 torr and Later with 29 torr. Segment 1 was obtained

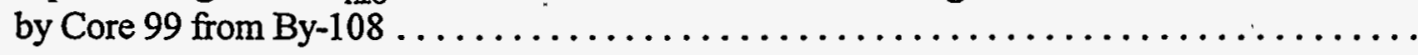

4.3 Thermal Behavior as Measured by TGA and DTA of Segment 1 Waste after Equilibrating with a $\mathrm{P}_{\mathrm{H} 2 \mathrm{O}}$ of 29 torr and Later with 2.2 torr. Segment 1 was obtained

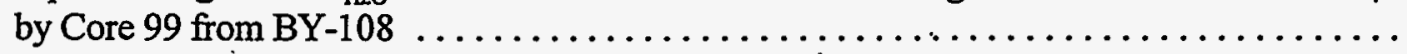

4.4 Effect of Exposure Time to Selected Partial Pressures of Water at $30^{\circ} \mathrm{C}$ on the Water Content of Waste Obtained by Core 99 Subsegment 2D from BY-108

4.5 Thermal Behavior as Measured by TGA and DTA of Subsegment 2D Waste after Equilibrating with a $\mathrm{P}_{\mathrm{H} 2 \mathrm{O}}$ of 2.2 torr and Later with 29 torr. Subsegment $2 \mathrm{D}$ was

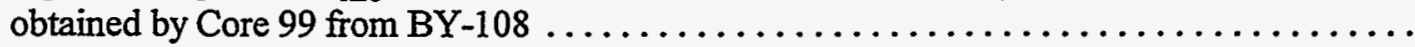

4.6 Thermal Behavior as Measured by TGA and DTA of Subsegment 2D Waste after Equilibrating with a $\mathrm{P}_{\mathrm{H} 2 \mathrm{O}}$ of 29 torr and Later with 2.2 torr. Subsegment 2D was

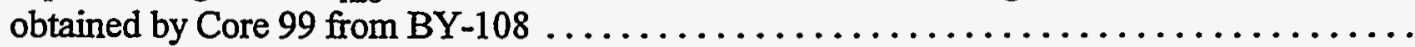

4.7 Effect of $\mathrm{P}_{\mathrm{H} 2 \mathrm{O}}$ on the Equilibrium Water Content of Waste Obtained by Core 99 Segment 1 and Subsegment 2D from BY-108

4.8 Thermal Behavior as Measured by TGA and DTA of Segment 1 Waste after Equilibrating with a $\mathrm{P}_{\mathrm{H} 2 \mathrm{O}}$ of 29 torr and Later with 2.2 torr, and Dried at $105^{\circ} \mathrm{C}$. Segment 1 was obtained by Core 99 from BY-108

4.9 Thermal Behavior as Measured by TGA and DTA of Segment 1 Waste after Equilibrating with a $\mathrm{P}_{\mathrm{H} 2 \mathrm{O}}$ of 2.2 torr and Later with 29 torr and Dried at $105^{\circ} \mathrm{C}$. Segment 1 was obtained by Core 99 from BY-108

4.10 Thermal Behavior as Measured by TGA and DTA of Subsegment 2D Waste after Equilibrating with a $\mathrm{P}_{\mathrm{H} 2 \mathrm{O}}$ of 29 torr and Later with 2.2 torr and Dried at $105^{\circ} \mathrm{C}$. Subsegment 2D was obtained by Core 99 from BY-108 
4.11 Thermal Behavior as Measured by TGA and DTA of Subsegment 2D Waste after Equilibrating with a $\mathrm{P}_{\mathrm{H} 2 \mathrm{O}}$ of 29 torr and Later with 2.2 torr and Dried at $105^{\circ} \mathrm{C}$ Subsegment 2D was obtained by Core 99 from BY-108. 


\section{Tables}

3.1 Elemental Concentrations Measured by ICP/AES for Waste Obtained by Core 99

Segment 1 and Subsegment 2D from BY-108

3.2 Anions, Total Organic and Inorganic Carbon, and Cyanide Content in Waste

Obtained by Core 99 Segment 1 and Subsection 2D from BY-108

4.1 Water Content of Waste Obtained by Core 99 Segment 1 and Subsegment

Equilibrated with 2.2 and 29 torr as Determined by Oven Drying at $105^{\circ} \mathrm{C}$ and TGA 


\subsection{Introduction}

Twenty of the 177 underground high level radioactive waste storage tanks at the U. S. Department of Energy's (DOE) Hanford Site have been identified as tanks that contain wastes that originally included or are suspected of containing potentially reactive combinations of organics and oxidants. Because these potentially hazardous chemical reactions could release radioactive materials to the environment, these 20 tanks have been placed on the Organic Tanks Watch List to ensure that special precautions and controls are used for all activities involving the tanks and the wastes stored in these tanks. These tanks are

$\begin{array}{llll}241-\mathrm{A}-101 & 241-\mathrm{S}-102 & 241-\mathrm{TX}-105 & 241-\mathrm{U}-106 \\ 241-\mathrm{A}-102 & 241-\mathrm{S}-111 & 241-\mathrm{TX}-118 & 241-\mathrm{U}-107 \\ 241-\mathrm{B}-103 & 241-\mathrm{SX}-103 & 241-\mathrm{TY}-104 & 241-\mathrm{U}-111 \\ 241-\mathrm{C}-102 & 241-\mathrm{SX}-106 & 241-\mathrm{U}-103 & 241-\mathrm{U}-203 \\ 241-\mathrm{C}-103 & 241-\mathrm{T}-111 & 241-\mathrm{U}-104 & 241-\mathrm{U}-204 .\end{array}$

Several interrelated factors control the potential for and the consequences of hazardous chemical reactions between the organics and the oxidants nitrate and nitrite present in the Hanford Site's stored radioactive wastes. These factors include the identities and concentrations of the organic fuel(s), the identities and concentrations of the oxidant(s), and the heat-absorption and heat-transfer properties of the waste and its surrounding environment, including the tank.

Water's heat-absorption and heat-transfer properties make it one of the primary common waste components that control whether hazardous self-sustaining reactions (Scheele et al. 1995) or propagating reactions (Fauske et al. 1995) can occur in an organic-bearing waste (Burger 1995; Fauske et al. 1995). The lower the water content, the greater the potential that energetic and vigorous reactions can occur. Because of water's efficiency for preventing propagating reactions, Webb et al. (1995) used water content as one of the bases for the criteria used to assess the potential chemical reactivity hazard of a Hanford Site's stored waste. These criteria are based.on 1) water content alone, 2) a combination of water content and total organic carbon (TOC), or 3) a combination of water content and reaction energetics.

Applying the Webb et al. criteria classifies the waste into the three waste safety categories of Safe, Conditionally Safe, and Unsafe. For a waste to be classified as Safe, not even minimal control of tank configuration is required to maintain the water content at or above $20 \mathrm{wt} \%$ (above $20 \mathrm{wt} \%$ water, a propagating reaction will not occur [Fauske et al. 1995]) or to satisfy the energetics or TOC criteria. If minimal controls are required to maintain the waste in a condition that satisfies the criteria, then the waste is classified as Conditionally Safe. If the waste does not satisfy the criteria, the waste is classified as Unsafe, and mitigation or remediation is required.

Because of water's importance in determining the hazard level of an organic-bearing waste, it is important to understand the factors that will control the water content in the waste and whether it will be necessary to actively control any of these factors to continue to ensure safe storage or to mitigate a future "unsafe" situation. Several factors control the waste's water content, including the water partial pressure 
$\left(\mathrm{P}_{\mathrm{H} 2 \mathrm{O}}\right)$ in the tank's headspace, the temperature of the waste, the temperature of the surrounding soil, the exchange rate of air within the tank with the outside air, the outside air's $\mathrm{P}_{\mathrm{H} 2 \mathrm{O}}$, and the strength of the chemical bond(s) between the waste and the retained water. For example, higher waste-water contents will occur at higher water partial pressures and lower waste temperatures or vice versa with lower water contents resulting from low water partial pressures and higher waste temperatures. In the long term, if the storage system is allowed to reach equilibrium with the ambient arid Hanford environment, the waste's water content will be determined by the $P_{\mathrm{H} 2 \mathrm{O}}$ in the tank's head space, which will be equivalent to or nearly equal to the ambient Hanford $\mathrm{P}_{\mathrm{H} 2 \mathrm{O}}$ provided in Figure 1.1.

In 1996 as part of PNNL's Organic Tank Safety Project, we developed and demonstrated a method to determine the effect of $\mathrm{P}_{\mathrm{H} 2 \mathrm{O}}$ on the equilibrium water content of Hanford's stored wastes, providing a means to predict a waste's future safety status or category. As a result of our development and demonstration effort, we determined the effect of $\mathrm{P}_{\mathrm{H} 2 \mathrm{O}}$ on selected potential waste components, surrogate waste mixtures made of those components, a simulated Hanford waste, and waste from Tank 241-T-111 (T-111) (Scheele, Bredt, and Sell 1996). These studies showed that the water content of Hanford wastes will depend on the individual waste components' identities and concentrations, temperature, and $\mathrm{P}_{\mathrm{Hz}}$. Before these studies and development effort, little was known about the response of Hanford wastes and their major components to $\mathrm{P}_{\mathrm{H} 2 \mathrm{O}}$, nor did the capability exist to measure accurately the effect of water partial pressures on the water content of radioactive Hanford wastes.

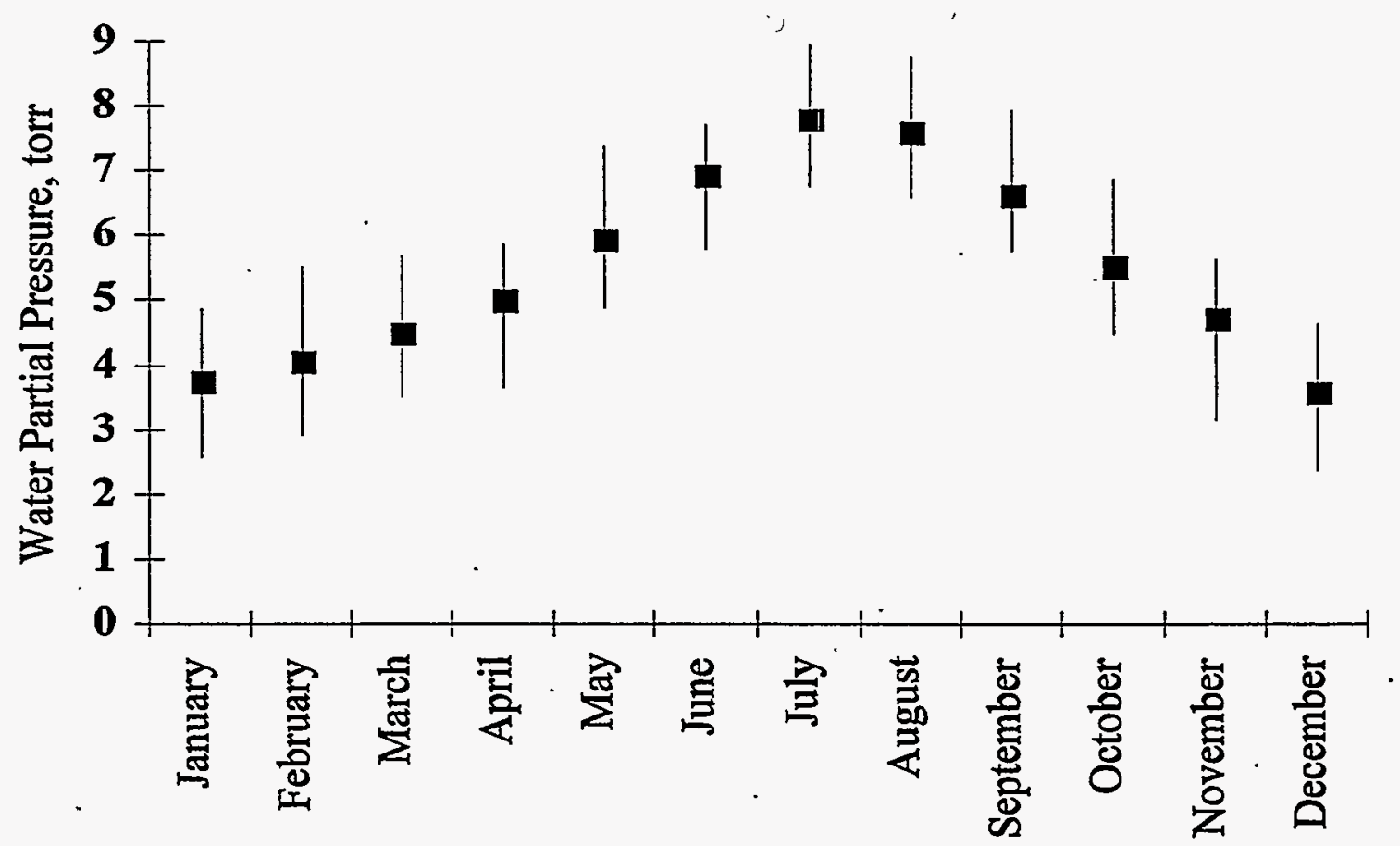

Figure 1.1 Average Hanford Monthly $P_{\mathrm{H} 2 \mathrm{O}}$ 1980-1995 (Data Provided by K. W. Burk of PNNL's Meteorological Group) (Scheele, Bredt, and Sell 1996) 
Continuing the effort to understand and predict the effect of $\mathrm{P}_{\mathrm{H} 2 \mathrm{O}}$ on the water content of Hanford wastes, we applied the developed method to determine the effect of $\mathrm{P}_{\mathrm{H} 2 \mathrm{O}}$ on the water content of waste from Tank 241-BY-108 (BY-108). Although the wastes stored in BY-108 are not on the Organic Tanks Watch List, the Organic Tank Safety Program selected it for study because D. A. Reynolds of Lockheed Martin Hanford identified the wastes in BY-108 as representative of saltcake wastes similar to many of the Hanford organic-bearing wastes, and samples were readily available. Webb et al. (1995) identified organic-bearing saltcake wastes as the organic-bearing wastes that are most likely to have Conditionally Safe compositions.

This report provides the results of studies on the effect of $P_{\mathrm{H} 2 \mathrm{O}}$ on the water content of two waste samples taken from the uppermost $55-\mathrm{cm}$ layer in BY-108. These results can be used to determine whether these wastes and similar wastes will require active management to ensure that they will retain sufficient water to be classified as Safe or Conditionally Safe even when allowed to equilibrate with ambient Hanford air. In addition, these studies could provide guidance on the $\mathrm{P}_{\mathrm{H} 2 \mathrm{O}}$ required to maintain or achieve the desired water content in a waste. 


\subsection{Experimental Approach and Method}

We used the general experimental approach and procedure developed in 1996 (Scheele, Bredt, and Sell 1996) to measure the equilibrium water content of waste samples taken from BY-108 when exposed to a range of water partial pressures expected during storage. These studies were conducted at the measured upper-level waste's temperature of $30^{\circ} \mathrm{C}$; the $\mathrm{P}_{\mathrm{H} 2 \mathrm{O}}$ ranged from 2 to 29 torr. The water partial pressures used encompass the minimum $\mathrm{P}_{\mathrm{H} 2 \mathrm{O}}$ observed at the Hanford Site between 1985 and 1995 and the higher water partial pressures that may exist in the tank.

Briefly, to determine the equilibrium water content of BY-108 waste, samples of waste were exposed to a controlled $\mathrm{P}_{\mathrm{H} 2 \mathrm{O}}$, the samples' masses were monitored until they stabilized, and the water content was determined by drying at $105^{\circ} \mathrm{C}$ to a stable mass and by using thermogravimetric analysis (TGA) for selected samples. We used the following procedure:

- Duplicate 1-g samples are placed in 20-mL glass vials, then placed in 500-mL sealed desiccators containing saturated solutions to control the $\mathrm{P}_{\mathrm{H} 2 \mathrm{O}}$ at particular levels, and then placed in a constant temperature oven. A schematic of this system is shown in Figure 2.1.

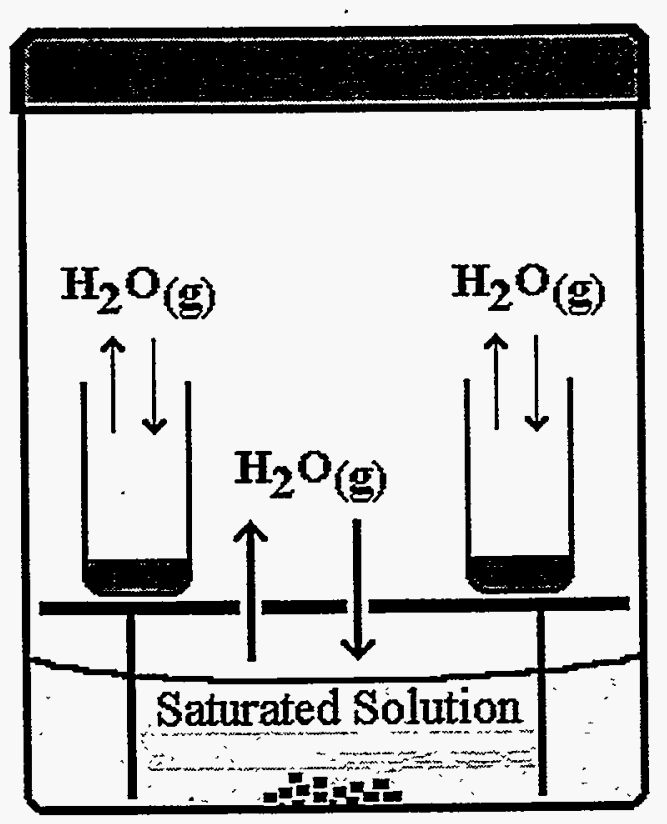

Figure 2.1. Schematic of Constant Humidity Chambers Used for Testing 
- The samples' masses are monitored frequently at first, with the frequency lessening to weekly intervals until the mass appears to be stabilizing. Then the frequency increased to 3-day intervals.

- Once the masses have stabilized over three successive 3-day intervals, samples exposed to the highest $\mathrm{P}_{\mathrm{H} 2 \mathrm{O}}$ and the lowest $\mathrm{P}_{\mathrm{H} 2 \mathrm{O}}$ are exchanged to investigate the reversibility of the water absorption and desorption. The samples' masses are monitored again until they stabilize, based on the same criteria used before. Subsamples are then taken from the highest $\mathrm{P}_{\mathrm{H} 2 \mathrm{O}}$ and the lowest $\mathrm{P}_{\mathrm{H} 2 \mathrm{O}}$ for TGA.

- The final equilibrium water contents are determined gravimetrically by drying at $105^{\circ} \mathrm{C}$ to a stable mass, and TGA is repeated on $105^{\circ} \mathrm{C}$ dried subsamples taken from the highest $\mathrm{P}_{\mathrm{H} 2 \mathrm{O}}$ and the lowest $\mathrm{P}_{\mathrm{H} 2 \mathrm{O}}$.

Because of temperature differences between our pure potential waste component studies and the BY-108 studies, we were unable to use the simple linear model based on the individual waste components' behavior (Scheele, Bredt, and Sell 1996) to predict the behavior of BY-108 waste. The studies of the pure potential waste constituents were done at 20 and $65^{\circ} \mathrm{C}$. The BY-108 studies were performed at $30^{\circ} \mathrm{C}$. A model based on measured chemical composition could be useful to predict the equilibrium water content of waste equilibrated with ambient Hanford air. 


\subsection{BY-108 Fill History, Temperatures, and Sample Composition}

Tank BY-108 was classed as a "Ferrocyanide Watch List Tank" based on historical records that indicated the waste stored in BY-108 contained $>8 \mathrm{wt} \%$ sodium nickel ferrocyanide on an energy equivalent basis (Hanlon 1996); this did not take into account any aging of the ferrocyanide that may have occurred during the years of storage (Lilga et al. 1992; 1993; 1994; 1995; 1996). The Hanford Site operating contractor used the Ferrocyanide Scavenging Process to remove radiocesium and to a lesser extent radiostrontium from aqueous wastes, thus allowing disposal of the decontaminated wastes to a soil column.

Although BY-108 is not currently on the Organic Watch List, the waste stored in BY-108 is a saltcake type waste and should be characteristic in many respects to some of the organic-bearing saltcake wastes stored in the Hanford Site's tanks that have been identified by Webb et al. (1995) as the wastes of greatest concern. Because of its saltcake characteristics and its ready availability to us, samples of waste taken by Core 99 segments 1 and 2D from BY-108 were studied to determine the equilibrium water content after exposure to a range of water partial pressures that it might experience during its storage as a result of environmental conditions or waste-management operations.

\subsection{Fill History}

Tank BY-108 was placed into service in March of 1951 and has been used to receive and store many different Hanford Site waste types. Tank BY-108 was the second tank in a cascade of three where overflow wastes from one tank could flow into and from another tank with waste flowing from BY-107 to BY-108 and then to BY-109. Much of the supernate was removed and disposed of in soil columns.

Baldwin et al. (1996) list many transfers in and out of the tank between 1951 and 1982. From 1951 to 1954 , the initial waste stream was 5.5 megaliters (ML) of first-cycle decontamination waste from the bismuth-phosphate process. Between 1954 and 1957, BY-108 was the primary settling tank for $33 \mathrm{ML}$ of U-Plant ferrocyanide-scavenged uranium recovery waste (Stedwell 1954). The resulting radiocesium decontaminated supernate was disposed of in soil columns. In 1957, 1.9 ML of ferrocyanidedecontaminated supernate was transferred to BY-108 from C-112. In 1959,1.9 ML of combined uranium recovery waste, cladding waste, and Plutonium Uranium Extraction (PUREX) cladding removal waste were transferred from C-105 to BY-108. Between 1969 and 1974, 3.3 ML of waste, including evaporator bottoms waste, cladding waste, and organic wash waste, were transferred from BY-109. Approximately 1.4 ML of in-tank solidification waste were transferred into BY-108 from BY-111 during 1968, and 2.3 ML of in-tank solidification waste were transferred from BY-112 between 1970 and 1971. Between 1972 and 1975 , approximately $0.1 \mathrm{ML}$ of water were added to the tank.

Tank BY-108 was classified as an assumed leaker in 1972 with an estimated leak of less than $20 \mathrm{~kL}$. While the reported tank volume has remained constant since 1982 at approximately $860 \mathrm{~kL}$ (Hanlon 1996; Baldwin et al. 1996), Baldwin et al. (1996) reports that drywell measurements indicate that "significant (radioactivity) was observed in the past (as expected from an assumed leaker)." Tank 
drywells located in the ground around the tank to monitor for leaks. The tank was interim stabilized in February 1985 by removing drainable liquid.

\subsection{Temperature}

Temperatures in Tank BY-108 range from 40 to $26^{\circ} \mathrm{C}$ bottom to top as measured by the one properly functioning thermocouple tree. This tree with 13 thermocouples is located in Riser 8 . Riser 8 located approximately $2 \mathrm{~m}$ north of the tank's center and is $18 \mathrm{~cm}$ in diameter. Thermocouple numbers 1 through 5 are located $15.2 \mathrm{~cm}, 76.2 \mathrm{~cm}, 137.2 \mathrm{~cm}, 198.2 \mathrm{~cm}$, and $259.2 \mathrm{~cm}$ from the bottom of the tank, respectively. The waste height is measured by a manual tape in Riser 4, approximately $4 \mathrm{~m}$ north of the center of the tank and $2 \mathrm{~m}$ north of the thermocouple tree in Riser 8. On October 1, 1995, the surface level in Riser 4 was measured at $220 \mathrm{~cm}$. This measured waste height places Thermocouples 1 through 4 in the waste and 5 in the headspace. Thermocouple readings on March 20,1996, for Thermocouples 1 through 5 were $41^{\circ} \mathrm{C}\left(106^{\circ} \mathrm{F}\right), 38^{\circ} \mathrm{C}\left(100^{\circ} \mathrm{F}\right), 33^{\circ} \mathrm{C}\left(91^{\circ} \mathrm{F}\right), 26^{\circ} \mathrm{C}\left(79^{\circ} \mathrm{F}\right)$, and $25^{\circ} \mathrm{C}\left(77^{\circ} \mathrm{F}\right)$, respectively. From these temperature data, $30^{\circ} \mathrm{C}\left(86^{\circ} \mathrm{F}\right)$ was determined to be at or near the waste surface temperature and used for the water equilibrium testing of BY-108.

\subsection{Core Sampling Event}

Three core samples were collected from BY-108 in July and August of 1995 using the rotary mode sampling truck. These core samples are referred to as Core 98, Core 99, and Core 104. Cores 98 and 99 were taken from Riser 12A, and Core 104 from Riser 7. Riser $12 \mathrm{~A}$ is $18 \mathrm{~cm}$ dia and approximately 8 meters north of the center of the tank. Cores 98 and 104 were extruded and analyzed at Westinghouse Hanford Company's (WHC) 222-S laboratory. Core 99 was extruded at WHC's 222-S laboratory and shipped to PNNL's 325 building Analytical Chemistry Laboratory for analysis.

Core 99 consisted of 4 segments. A full segment is $48 \mathrm{~cm}$ in length. Segments are numbered starting from the top of the waste, so Segment 1 will contain material from the surface of the waste. Segment 1 in Core 99 contained approximately $5 \mathrm{~cm}$ of solids and no drainable liquid. Baldwin et al. (1996) described the material as a dirty white saltcake. Segment 2 contained $230 \mathrm{~mL}$ of an opaque yellow-green drainable liquid and approximately $5 \mathrm{~cm}$ of solids. The solids were divided into two $2.5 \mathrm{-cm}$ subsamples referred to as Quarter Segment 2A and Quarter Segment 2D. Quarter Segment 2A was described as a dirty-white saltcake, and Quarter Segment 2D as a cream-colored sludge; the subsequent 2D sample tested was a light brown moist grainy material. Segment 3 contained $25 \mathrm{~mL}$ of tan-colored opaque drainable liquid and $2.5 \mathrm{~cm}$ of grainy cream-colored saltcake. Segment 4 contained $48 \mathrm{~cm}$ of a brown sludge with embedded saltcake and no drainable liquid. The material in Segment 4 was divided into four quarter segments labeled 4A through 4D.

All samples were homogenized at PNNL using a mortar and pestle before any analysis and before removing subsamples for moisture equilibrium testing reported here. Given the limited volume of material, PNNL's high shear blender, which is normally used for homogenization, could not be used for this homogenization. Elemental contents as measured by inductively coupled argon plasma coupled with atomic emission spectroscopy (ICP/AES) and gamma energy analysis (GEA) in duplicate subsamples from 
Segment 1 and Quarter Segment 4B were compared to determine if the homogenization was effective. The results reported by Silvers et al. ${ }^{(a)}$ showed inhomogeneity between duplicates. The highest relative percent difference between duplicates, $42 \%$, was seen for iron.

\subsection{Composition}

Selected compositional data collected on Segments 1 and 2D from Core 99 used in our equilibriumwater-content studies were taken from Baldwin et al. (1996) and Silvers et al. ${ }^{\text {(a) }}$ Their references include data collected for Cores 98, 99, and 104.

Water content in Segments 1 and 2D, the samples used for our moisture testing, were $29 \mathrm{wt} \%$ and $17 \mathrm{wt} \%$ water, respectively, as measured by TGA. The mass losses observed between ambient and approximately $150^{\circ} \mathrm{C}$ for Segment 1 and from ambient to approximately $200^{\circ} \mathrm{C}$ for Segment 2D were assigned to water loss.

As shown in Tables 3.1 and 3.2, the major elements, anions, and other measured constituents in Segments 1 and 2D are aluminum, sodium, phosphorous principally as phosphate, nitrate, nitrite, and sulfate, and fluoride, although significant compositional differences exist between the two segments. Both segments have traces of carbonate and/or bicarbonate (total inorganic carbon [TIC]) and TOC; the TOC is in excess of the carbon associated with the cyanide. The elemental concentrations provided in Table 3.1 on a dry basis were determined by ICP/AES of acidic solutions prepared from both $\mathrm{KOH}-\mathrm{KNO}_{3}$ fusions and $\mathrm{Na}_{2} \mathrm{O}_{2}-\mathrm{NaOH}$ fusions. Table 3.2 provides the cyanide, TOC, TIC, and anion concentrations on a dry basis; the anion concentrations were measured using ion chromatography (IC). None of the samples from BY-108 were analyzed for [ $\left.\mathrm{OH}^{-}\right]$, a major water absorbing waste constituent (Scheele, Bredt, and Sell 1996; Fauske et al. 1995; Barney 1976).

(a) Silvers, K. L., L. R. Greenwood, R. T. Steele, J. M. Tingey, M. W. Urie. 1995. Single Shell Tank Waste Characterization Project, Core 99, Revision 1. A letter report to Westinghouse Hanford Company. Pacific Northwest National Laboratory, Richland, Washington. 
Table 3.1. Elemental Concentrations Measured by ICP/AES for Waste Obtained by Core 99 Segment 1 and Subsegment 2D from BY-108. Units are $\mu \mathrm{g} / \mathrm{g}$ of dry waste.

\begin{tabular}{|c|c|c|c|c|}
\hline & \multicolumn{2}{|c|}{$\mathrm{KOH}-\mathrm{KNO}_{3}$ Fusion } & \multicolumn{2}{|c|}{$\mathrm{Na}_{2} \mathrm{O}_{2}-\mathrm{NaOH}$ Fusion } \\
\hline Element & Segment 1 & Subsegment 2D & Segment 1 & Subsegment 2D \\
\hline $\mathrm{Al}$ & 200,000 & 83,000 & 160,000 & 73,000 \\
\hline $\mathrm{Ca}$ & 1,000 & 1,100 & $4,900^{(a)}$ & $3,100^{(a)}$ \\
\hline $\mathrm{Fe}$ & 2,100 & 1,100 & 1,700 & 650 \\
\hline $\mathrm{K}$ & (b) & (b) & 8,900 & 5,300 \\
\hline $\mathrm{Na}$ & 140,000 & 170,000 & (b) & (b) \\
\hline $\mathbf{P}$ & 35,000 & 2,900 & $5,400^{(c)}$ & $280^{(c)}$ \\
\hline Si & 10,000 & 1,400 & 4,800 & 1,300 \\
\hline \multicolumn{5}{|c|}{$\begin{array}{l}\text { (a) } 3,700 \mu \mathrm{g} / \mathrm{g} \text { detected in process blank. } \\
\text { (b) Not measured due to fusion technique. } \\
\text { (c) Zirconium crucibles used, so low results due to precipitation of zirconium } \\
\text { phosphate. }\end{array}$} \\
\hline
\end{tabular}

Table 3.2. Anions, Total Organic and Inorganic Carbon, and Cyanide Content in Waste Obtained by Core 99 Segment 1 and Subsegment 2D from BY-108. Units are in $\mu \mathrm{g} / \mathrm{g}$ of dry waste.

\begin{tabular}{|c|c|c||}
\hline Analyte & Segment 1 & Subsegment 2D \\
\hline $\mathrm{CN}^{-}$ & 130 & 170 \\
\hline $\mathrm{TOC}$ & 1,500 & 2,800 \\
\hline $\mathrm{TIC}$ & 1,700 & 2,900 \\
\hline $\mathrm{F}^{-}$ & 8,500 & 4,700 \\
\hline $\mathrm{Cl}^{-}$ & 990 & 1,400 \\
\hline $\mathrm{NO}_{2}^{-}$ & 11,000 & 24,000 \\
\hline $\mathrm{NO}_{3}^{-}$ & 86,000 & 300,000 \\
\hline $\mathrm{PO}_{4}{ }^{--}$ & 82,000 & 17,000 \\
\hline $\mathrm{SO}_{4}{ }^{2-}$ & 1,700 & 12,000 \\
\hline
\end{tabular}




\subsection{Water Retention of BY-108 Waste .}

Samples taken from Segment 1 and Subsegment 2D of the Core 99 sampling event from BY-108 were exposed to partial pressures of water of $2.2,7.6,18,27$, and 29 torr at $30^{\circ} \mathrm{C}$ to determine the equilibrium water contents of a characteristic saltcake waste. After stable masses were reached, samples in the 2.2 and 29 torr vessels were exchanged and their masses monitored until stable or deliquescing and forming a drainable liquid. Samples in the 2.2 and 29 torr water vapor baths were then analyzed simultaneously by TGA and differential thermal analysis (DTA). These two samples were chosen for TGA DTA to assess the difference in thermal behavior between the extremes in water content and to determine if different types of water are present in BY-108 waste. Samples previously in the 2.2 and 29 torr vessels were then reanalyzed by TGA/DTA. All water contents used in the following discussion are based on the water content determined gravimetricly after drying at $105^{\circ} \mathrm{C}$.

\subsection{Water Content Versus Time}

To determine the effect of $\mathrm{P}_{\mathrm{H} 2 \mathrm{O}}$ on the equilibrium water content of the characteristic saltcake waste in BY-108, samples of waste from Core 99 Segment 1 and Subsegment 2D taken from BY-108 were exposed to selected water partial pressures. Their masses were monitored until they stabilized or were beginning to approach a stable mass. In addition to the final equilibrium water content, the water sorption and desorption behavior as a function of time provides information on the nature of the wastes and the types of water retained by these two waste samples. The water content of these two samples during the course of the experiment is given here in addition to the TGA/DTA analyses after the experiments were completed.

The reader is reminded that although we are providing water sorption or desorption as a function of time, differences in surface area, particle size, and particle shape between the tested samples and the waste in the tank will cause differences in the kinetics of water sorption and desorption. Because of potential differences in sorption/desorption kinetics, the absolute kinetic results presented here must be applied cautiously to the behavior of actual wastes. Another limit on the ability to use these data for predicting rates in the actual tank is the small sample size used for this testing. These smaller samples have shorter transport distances and, therefore, this effect will decrease the equilibration time.

\subsubsection{Behavior of Segment 1 Waste}

As shown in Figure 4.1, the Segment 1 samples, which contained about $13 \mathrm{wt} \%$ water when testing began, exposed to $7.6,18,27$, and 29 torr water reached their average equilibrium water contents of 15 , 17,37 , and $48 \mathrm{wt} \%$ within the first $1000 \mathrm{~h}$. The duplicate samples exposed to 2.2 torr required $1079 \mathrm{~h} \mathrm{to}$ reach equilibrium water contents of 0 and 2 wt\% water (average of 1 ) before being transferred to the 29 torr bath. Water contents of the duplicate samples had relative percent differences (RPD) of approximately $280,17,4,9$, and $1 \%$ at $2.2,7.6,18,27$, and 29 torr water, respectively. The high RPD for the 2.2 torr samples is not surprising given the low equilibrium water content noted above. The most likely explanation for high relative percent differences in the remaining baths is sample inhomogeneity resulting from the mortar and pestle homogenization technique used for these samples. 


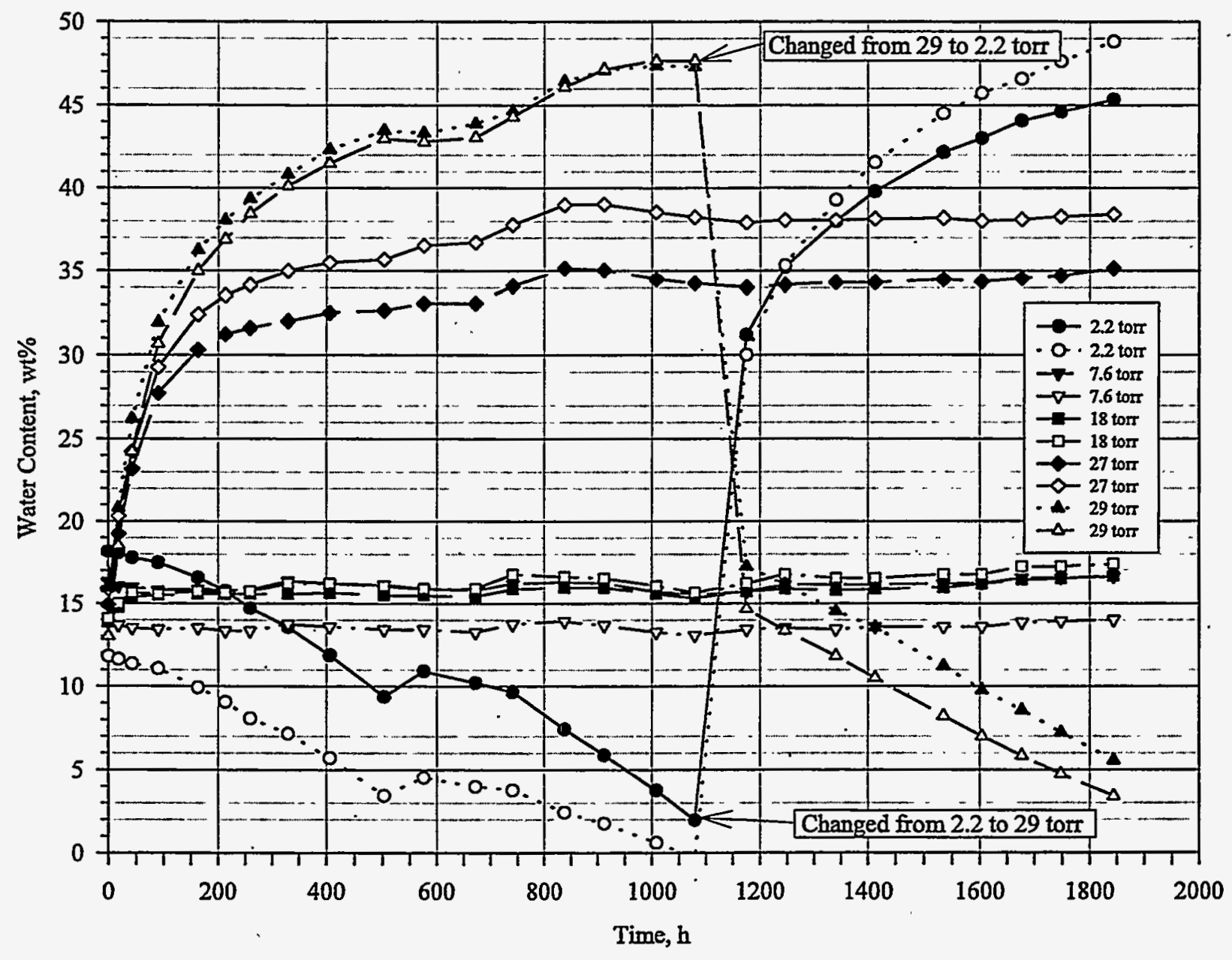

Figure 4.1. Effect of Exposure Time to Selected Partial Pressures of Water at $30^{\circ} \mathrm{C}$ on the Water Content of Waste Samples Obtained by Core 99 Segment 1 from BY-108

The behaviors observed for the exchanged samples in the 2.2 torr and 29 torr vessels after stable or near-stable masses were reached after $1079 \mathrm{~h}$ indicate that the observed water contents are a true equilibrium and that the sorption and desorption of water is reversible. As shown in Figure 4.1, Segment 1 samples initially equilibrated with 29 torr water when exposed to 2.2 torr water initially lost mass rapidly (48 to $15 \mathrm{wt} \%$ in $100 \mathrm{~h}$ ). After drying to $15 \mathrm{wt} \%$, however, the water loss rate slowed, and as a result, these samples did not reach stable masses before the testing was ended; the continued downward trend indicates that these Segment 1 samples would continue to drop to nearly $0 \mathrm{wt} \%$ water as the samples initially exposed to 2.2 torr of water did. The difference in water loss rates above and below $15 \mathrm{wt} \%$ water content suggests that above. $15 \mathrm{wt} \%$, the water retained by Segment 1 waste is of two different types. The samples initially exposed to 2.2 torr and then exposed to 29 torr exhibited similar sorption behavior to the samples initially exposed to 29 torr after reaching $30 \mathrm{wt} \%$ water in about $100 \mathrm{~h}$ and reaching an average $47 \mathrm{wt} \%$ water after another $700 \mathrm{~h}$. 
The TGA, the differential of the TGA (DTG), and the DTA analyses of the Segment 1 samples exposed to a final $\mathrm{P}_{\mathrm{H} 2 \mathrm{O}}$ of 29 torr (Figure 4.2) also indicate that two types of water exist above $15 \mathrm{wt} \%$, assuming that the mass losses below $150^{\circ} \mathrm{C}$ are due to water loss. Below $150^{\circ} \mathrm{C}$, two separate endothermic mass losses are observed, indicating that Segment 1 waste retains two different types of water.

- The cause of the endothermic mass loss observed beginning at $220^{\circ} \mathrm{C}$ is unknown, but similar events are observed for wastes from $\mathrm{C}-109$ that contained wastes resulting from the ferrocyanide In-Farm radiocesium scavenging process (Scheele et al. 1994).

The TGA, DTG, and DTA analyses of the Segment 1 samples exposed to a final 2.2 torr of water indicate that only a single type of water remains in these dry samples (see Figure 4.3). This is also consistent with the water release data observed for the samples exposed to high $\mathrm{P}_{\mathrm{H} 2 \mathrm{O}}$.

\subsubsection{Behavior of Subsegment 2D Waste}

As shown in Figure 4.4, the Subsegment 2D samples, which began at about $10 \mathrm{wt} \%$ of water, exposed to $2.2,7.6,18,27$, and 29 torr reached equilibrium or terminal water contents averaging $0.3,5,12,55$, and $62 \mathrm{wt} \%$, respectively. Segment $2 \mathrm{D}$ samples exposed to $2.2,7.6$, and 18 torr reached equilibrium masses within the first $300 \mathrm{~h}$, while samples exposed to 27 and 29 torr were still gaining water after $500 \mathrm{~h}$ of exposure. Duplicate samples had RPDs of approximately $290,42,5,1$, and $0.1 \%$ at $2.2,7.6,18,27$, and 29 torr, respectively. As with Segment 1, the high RPD at 2.2 torr is expected, given the low water content. The average wt $\%$ of water at 2.2 torr was $0.3 \%$, which is so low that a value of 0 will be used in this report. The RPD of $42 \%$ at 7.6 torr is believed to be the result of inhomogeneity within the original sample.

The behavior of the Subsegment 2D samples before and after being exchanged between the 2.2 torr and 29 torr vessels after $503 \mathrm{~h}$ indicate that the observed water contents are a true equilibrium and that the sorption and desorption of water is reversible. As shown in Figure 4.2, after being exchanged, the Subsegment 2D samples exposed to 2.2 and 29 torr of water achieved water contents of 2 and $67 \mathrm{wt} \%$, respectively, that are nearly the same as the 0 and $62 \mathrm{wt} \%$ for the equivalent $\mathrm{P}_{\mathrm{H} 2 \mathrm{O}}$ exposures, respectively. The similarity in the water sorption and desorption curves for the exchanged Subsegment $2 \mathrm{D}$ samples suggests most if not all the water sorbed by the waste in Subsegment 2D waste is the same, with little tightly sorbed water.

The large endothermic mass loss observed in the TGAs and DTAs of the Subsegment 2D samples exposed to a final 29 torr of water (Figure 4.5) provides additional evidence that the majority of the water retained by this sample of waste is a single type of water, likely the so-called free water. The two peaks observed in the DTG and DTA curves with peak maximums at $125^{\circ} \mathrm{C}$ and $135^{\circ} \mathrm{C}$ indicate, however, that this material contains two other types of water, likely a hydrate. This again assumes that any mass losses observed below $150^{\circ} \mathrm{C}$ are due to water.

The TGAs and DTAs of the Subsegment 2D samples exposed to a final 2.2 torr of water (Figure 4.6) indicate that a single type of water exists in Subsegment 2D material exposed to a very dry environment. The single small mass loss observed below $150^{\circ} \mathrm{C}$ occurs between $50^{\circ} \mathrm{C}$ and $100^{\circ} \mathrm{C}$; the absence of the 


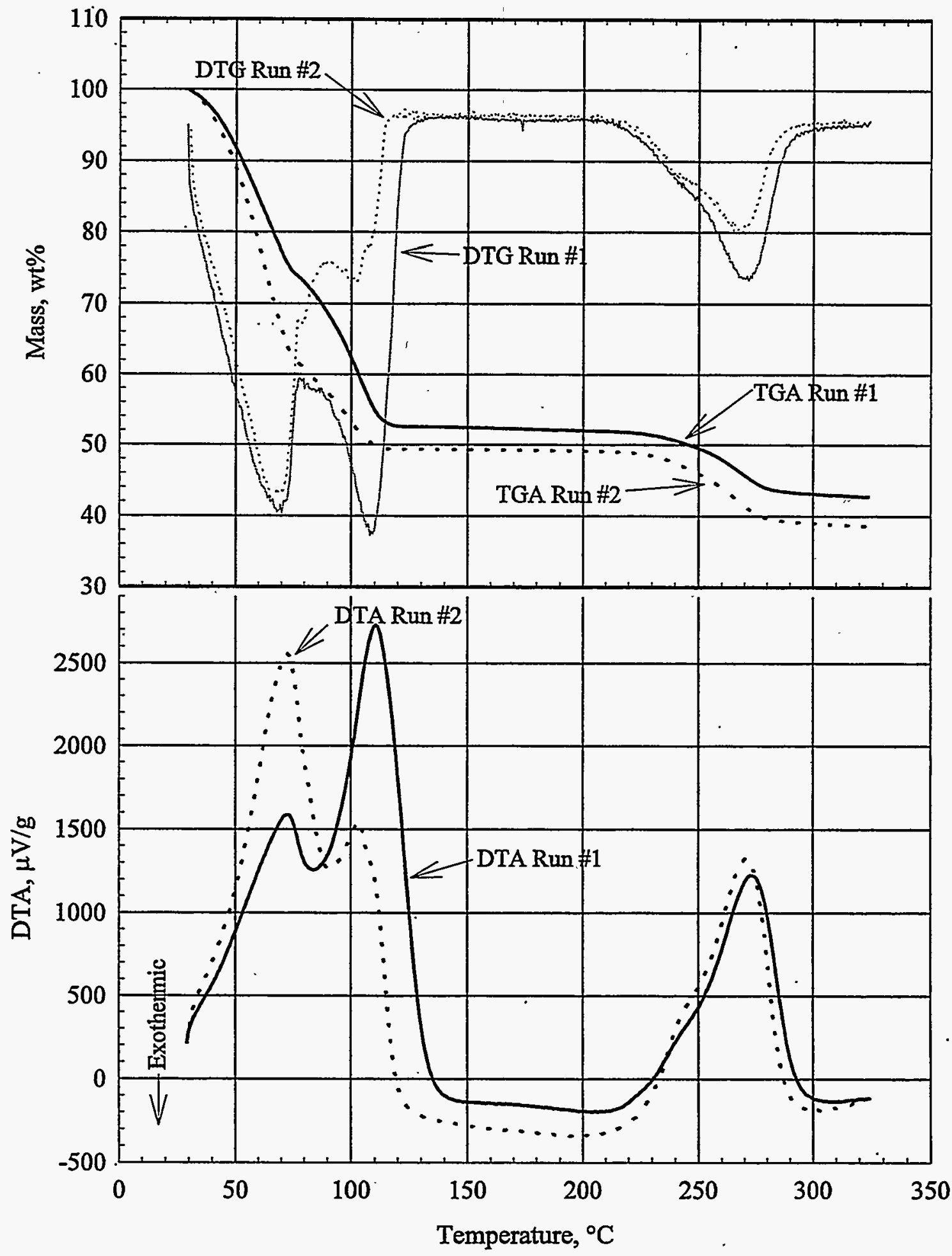

Figure 4.2. Thermal Behavior as Measured by TGA and DTA of Segment 1 Waste after Equilibrating with a $\mathrm{P}_{\mathrm{H} 2 \mathrm{O}}$ of 2.2 torr and Later with 29 torr. Segment 1 was obtained by Core 99 from BY-108 


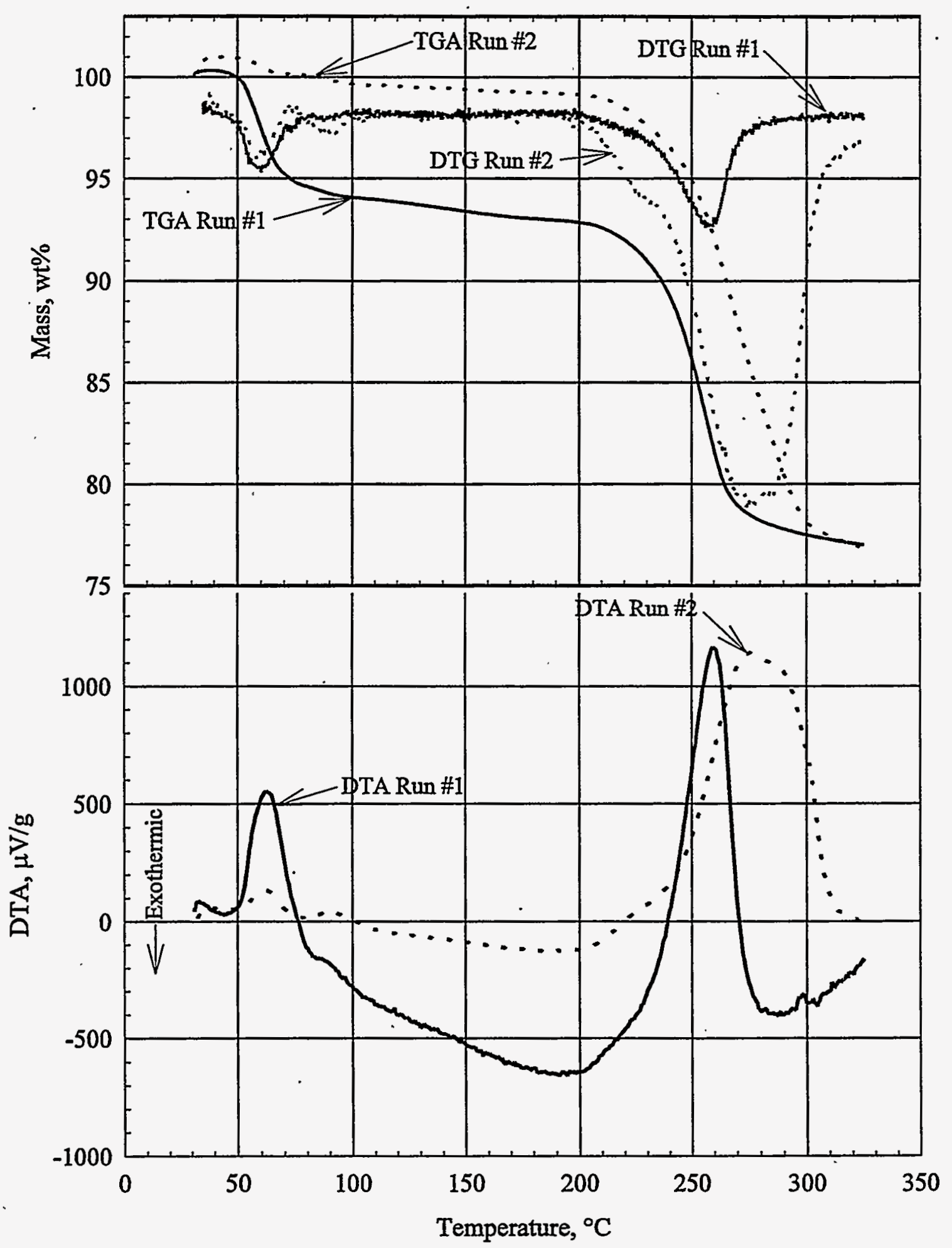

Figure 4.3. Thermal Behavior as Measured by TGA and DTA of Segment 1 Waste after Equilibrating with a $\mathrm{P}_{\mathrm{H} 2 \mathrm{O}}$ of 29 torr and Later with 2.2 torr. Segment 1 was obtained by Core 99 from BY-108 


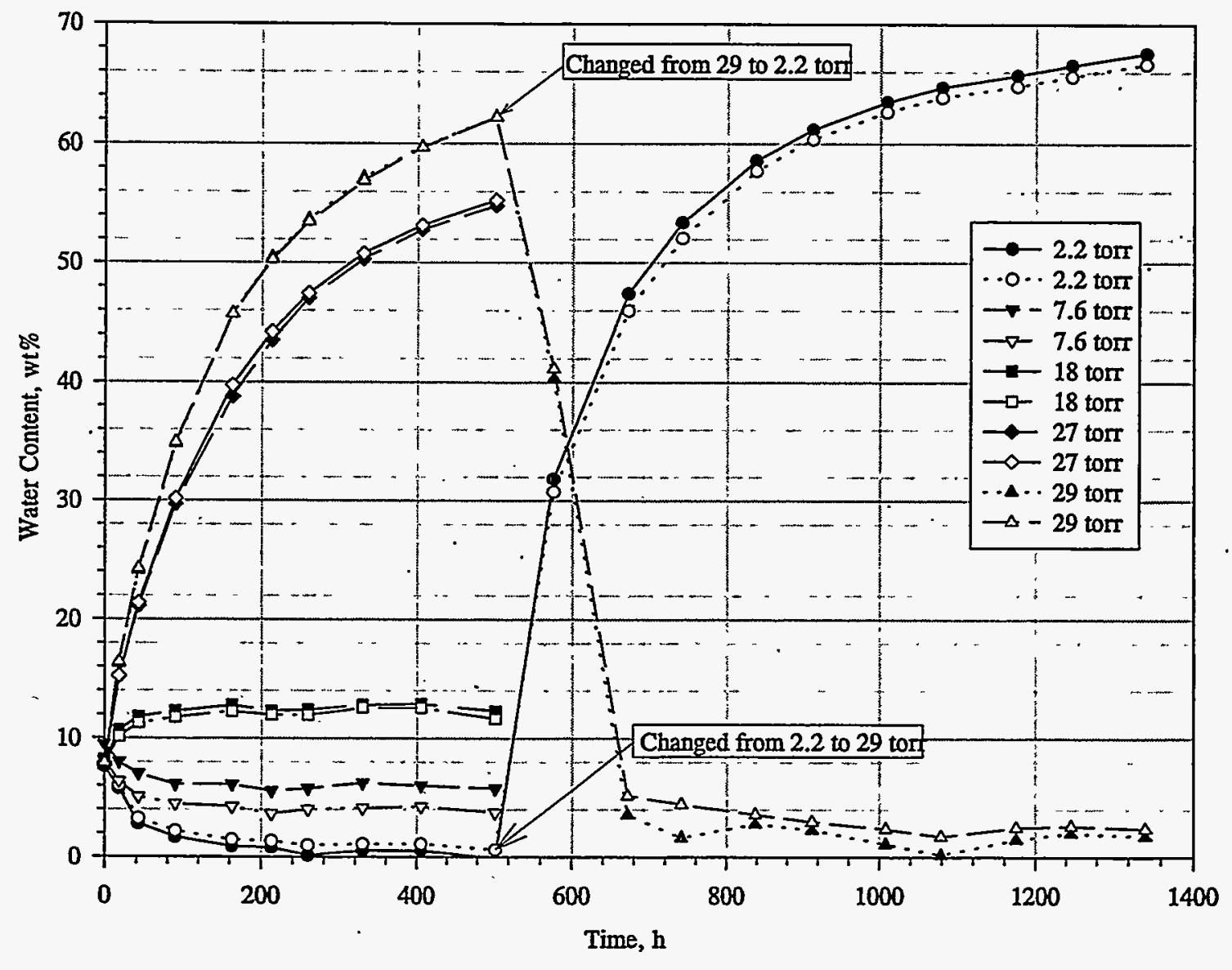

Figure 4.4. Effect of Exposure Time to Selected Partial Pressures of Water at $30^{\circ} \mathrm{C}$ on the Water Content of Waste Obtained by Core 99 Subsegment 2D from BY-108

two peaks observed with peak maximum at $125^{\circ} \mathrm{C}$ and $135^{\circ} \mathrm{C}$ for the material exposed to a final 29 torr provides evidence that they are actually due to water loss. The absence of these two types of water in the dry sample indicates that, with time, these waters can evaporate.

Comparing the water sorption and desorption behavior and thermal analyses of the equilibrated samples of waste obtained from BY-108 by Segment 1 and Subsegment $2 \mathrm{D}$ indicates that differences exist between the water retained by these two different materials. Comparing the drying curves for the two materials hydrated at 29 torr and then exposed to 2.2 torr indicates that most of the water retained by Subsegment 2D is easily and quickly removed. A larger fraction of the water retained by Segment 1 is more difficult to remove and requires more time to remove. Comparing kinetic results directly assumes that the two materials have similar particle sizes and other physical properties discussed earlier. Comparing the TGAs and DTAs in Figures 4.2 and 4.6 also illustrates the differences between the water in the two materials with the Segment 1 samples having two significant types of water below $100^{\circ} \mathrm{C}$. Subsegment $2 \mathrm{D}$ samples have only one type of water below $100^{\circ} \mathrm{C}$ and another two types between 100 and $150^{\circ} \mathrm{C}$. 


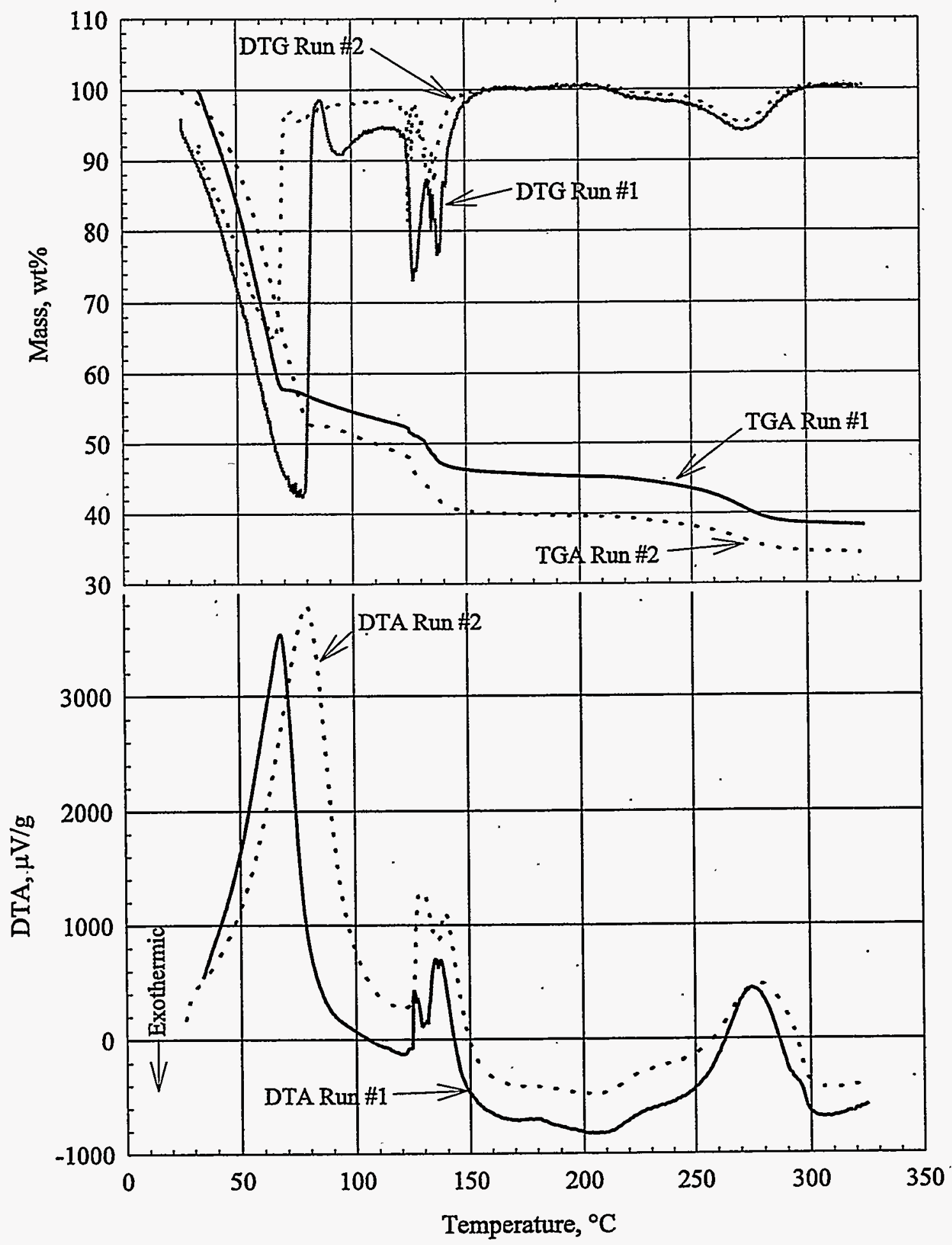

Figure 4.5. Thermal Behavior as Measured by TGA and DTA of Subsegment 2D Waste after Equilibrating with a $\mathrm{P}_{\mathrm{H} 2 \mathrm{O}}$ of 2.2 torr and Later with 29 torr. Subsegment 2D was obtained by Core 99 from BY-108 


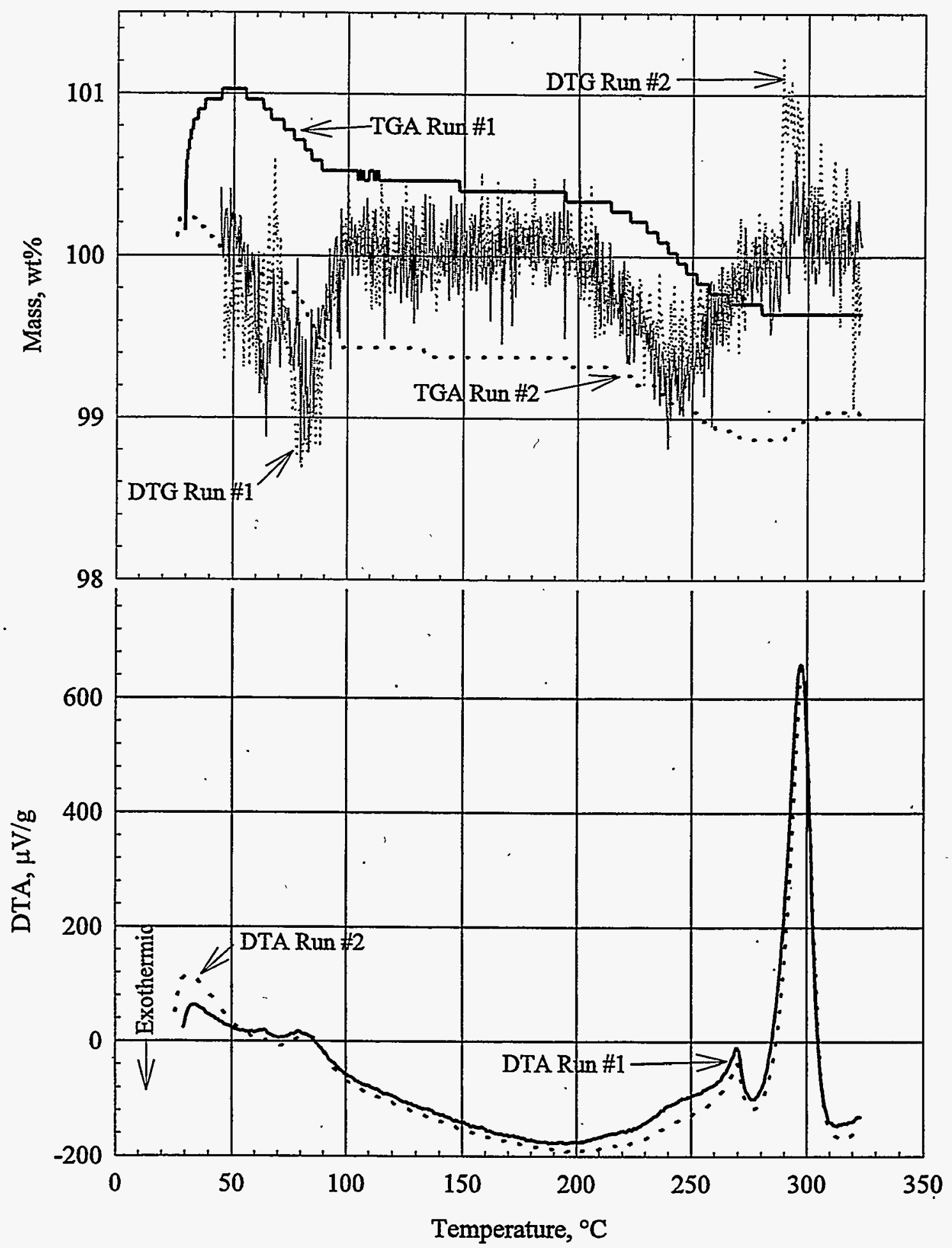

Figure 4.6. Thermal Behavior as Measured by TGA and DTA of Subsegment 2D Waste after Equilibrating with a $\mathrm{P}_{\mathrm{H} 2 \mathrm{O}}$ of 29 torr and Later with 2.2 torr. Subsegment $2 \mathrm{D}$ was obtained by Core 99 from BY-108 
The sorption/desorption reversibility shows that for these two materials from BY-108 on a chemical basis, it may be possible to mitigate a lower than acceptable waste water content (Webb et al. 1995) by treating this waste or other similar wastes with air having a controlled $\mathrm{P}_{\mathrm{H} 2 \mathrm{O}}$ to rehydrate the waste. However, some caútion should be used when applying the equilibrium water content results for the high $\mathrm{P}_{\mathrm{H} 2 \mathrm{O}}$ exposures when planning a remediation strategy. Because the sample size and vial geometry used in this testing prevent free flowing liquid from draining, as is possible in the actual tank, the high $\mathrm{P}_{\mathrm{H} 2 \mathrm{O}}$ test sam-

ples could have a higher water content than that in a similarly exposed tank. In addition, samples used for this work were homogenized, so the crystal sizes, crystal shapes, and resulting pore sizes and volumes could differ from that of the actual tank. As a result of the potential differences in these physical parameters, the retention of pore water could be different for actual in-tank waste at high $\mathrm{P}_{\mathrm{H} 2 \mathrm{O}}$ where drainable liquids could be present. However, the water contained in the lower $\mathrm{P}_{\mathrm{H} 2 \mathrm{O}}$ samples is most likely contained in or on the solid particles and should be very similar to the values that would be achieved in the actual tank.

\subsection{Effect of $P_{\mathrm{H} 2 \mathrm{O}}$ on Equilibrium Water Content}

The effect of $\mathrm{P}_{\mathrm{H} 2 \mathrm{O}}$ on the equilibrium water content is presented in Figure 4.7 for Segments 1 and 2D. The equilibrium water contents for Segment 1 are $1,15,17,36$, and 48 for water partial pressures of 2.2, $7.6,18,27$, and 29 torr, respectively. Subsegment $2 \mathrm{D}$ had water contents of $1,5,12,55$, and 62 at the same water partial pressures. While Segment 1 has a higher equilibrium water content at water partial pressures below 18 torr, $15 \mathrm{wt} \%$ for Segment 1 versus $5 \mathrm{wt} \%$ for Subsegment $2 \mathrm{D}$ at 7.6 torr, the weight fraction water for Subsegment 2D exceeds that for Segment 1 at water partial pressures greater than approximately 20 torr.

The differences between the two waste samples likely arise from higher concentrations of phosphate and aluminum in Segment 1 and higher nitrate and nitrite concentrations in Subsegment 2D. The water content below 20 torr could be due to the higher concentration of $\mathrm{PO}_{4}^{3-}$ and $\mathrm{Al}$ in Segment 1 , 82,000 wppm $\mathrm{PO}_{4}{ }^{3-}$ in Segment 1 compared to 17,000 wppm in Subsegment 2D, and 200,000 wppm Al in Segment 1 compared to 83,000 wppm in Subsegment 2D. Based on our earlier work at $22^{\circ} \mathrm{C}$ (Scheele, Bredt, and Sell 1996), the higher $\mathrm{NO}_{3}^{-}$concentrations in Subsegment 2D, 300,000 wppm in Subsegment $2 \mathrm{D}$ compared to $86,000 \mathrm{wppm}$ for Segment 1 , probably cause the higher water content for Subsegment 2D material above 20 torr of water; our earlier studies showed that mixtures of $\mathrm{NaNO}_{3}$ and $\mathrm{NaNO}_{2}$ begin to absorb significant amounts of water between 14 and 17 torr. We can only postulate that these compositional differences caused the differences in water contents because our sodium aluminate studies yielded confounded results (Scheele, Bredt, and Sell 1996) and no reports were found on the effect of $\mathrm{P}_{\mathrm{H} 2 \mathrm{O}}$ on water content of $\mathrm{Al}$ and $\mathrm{PO}_{4}^{3-}$ in the forms potentially present in Hanford waste tanks.

In general, exposing the BY-108 saltcake wastes to ambient Hanford water partial pressures will cause the waste to dry from Segment 1's $29 \mathrm{wt} \%$ water at the time of the original core analysis, and Subsegment 2D's $16.7 \mathrm{wt} \%$ water (Baldwin et al. 1996). The average Hanford $\mathrm{P}_{\mathrm{H} 2 \mathrm{O}}$ is approximately 5.5 torr with monthly highs up to 9 torr in the summer and lows down to 2.5 torr in the winter (Figure 1.1). The equilibrium water contents for Segment 1 are 1,15 , and $17 \mathrm{wt} \%$ at $2.2,7.6$, and 18 torr respectively. Therefore, at all current ambient Hanford partial pressures of water, the waste in Segment 1 


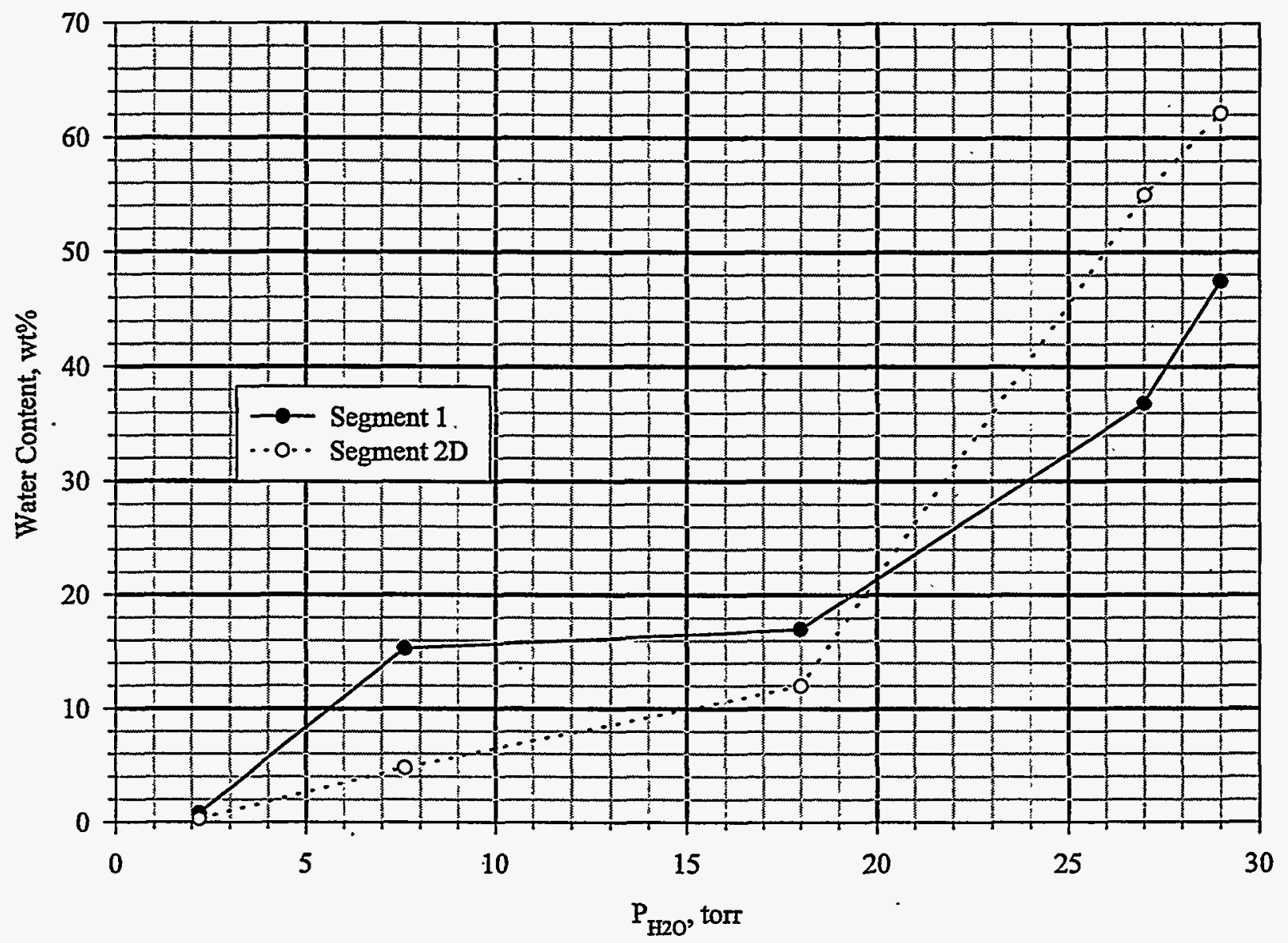

Figure 4.7. Effect of $\mathrm{P}_{\mathrm{H} 2 \mathrm{O}}$ on Equilibrium Water Content of Waste Samples Segment 1 and Subsegment 2D Obtained by Core 99 from BY-108

will dry below the current TOC and energetics independent safety criterion of $20 \mathrm{wt} \%$ water (Webb et al. 1995). The same situation exists for Subsegment 2D, with equilibrium water contents of 0,5 , and 12 at $2.2,7.6$ and 18 torr, respectively. It should be noted that Subsegment 2D's $16.7 \mathrm{wt} \%$ water is already below this safety criterion. For the top $100 \mathrm{~cm}$ of waste in BY-108 to remain above the safety limit of 20 wt $\%$ water, the material would have to be exposed to pressure near or above 20 torr of water vapor. Under current conditions, at an average ambient Hanford water vapor pressure of 5.5 torr, the waste in Segment 1 should dry to an equilibrium water content of approximately $10 \mathrm{wt} \%$, and Subsegment 2D should dry to approximately $3 \mathrm{wt} \%$ water.

Based on the measured behavior of Segment 1 and its reported water content of $30 \mathrm{wt} \%$ (Baldwin et al. 1996), the equilibrium $\mathrm{P}_{\mathrm{H} 2 \mathrm{O}}$ for the upper layer of material in $\mathrm{BY}-108$ should be about 23 torr. The measured $P_{H 2 O}$ in the head space of BY-108 was 14.8 torr (Pool et al. 1996) on January 24, 1996 when the temperature in the head space measured in riser 8 was $24^{\circ} \mathrm{C}$. The equilibrium vapor pressure of pure water is 22.4 torr at $24^{\circ} \mathrm{C}$ (Weast, Astle, and Beyer 1984). At the average Hanford soil temperature of about $17^{\circ} \mathrm{C}$ (Barney 1976) water's $P_{\mathrm{H} 2 O}$ is 14.5 torr (Weast, Astle, and Beyer 1984). Because the 
measured $\mathrm{P}_{\mathrm{H} 2 \mathrm{O}}$ in the head space is less than both the vapor pressure of water at the headspace temperature and the equilibrium $\mathrm{P}_{\mathrm{H} 2 \mathrm{O}}$ for the uppermost segment, it appears that either the environment exchanges air significantly with BY-108 (breathing) or, alternatively, the water content in the head space is controlled by the temperature of the tank's wall and the surrounding soil with condensation of water on the wall's surface. If there is significant tank breathing, eventually the waste's water content should be controlled by the equilibrium with ambient Hanford air.

As discussed in the Experimental Section, we determined the water content of all equilibrated BY-108 wastes gravimetrically by drying at $105^{\circ} \mathrm{C}$ and analyzing selected samples by TGA. Because several types of water can exist in water-waste mixtures (Scheele, Bredt, and Sell 1996), all with different bonding energies, we analyzed the BY- 108 wastes equilibrated at 2.2 and 29 torr before and after drying at $105^{\circ} \mathrm{C}$ using TGA and DTA to help try to determine the different types of water that were present in the equilibrated waste. The TGA/DTAs for these BY- 108 samples before drying at $105^{\circ} \mathrm{C}$ were presented earlier, see Figures 4.2 through 4.5; Figures 4.8 through 4.11 present the TGA/DTAs for these samples after drying at $105^{\circ} \mathrm{C}$. Comparison of the TGA/DTAs of the same samples before and after drying shows that, in general, heating at $105^{\circ} \mathrm{C}$ until a stable mass is reached is an effective drying method for BY-108 wastes, although higher temperatures are required for some of the waters when heated at $5^{\circ} \mathrm{C} / \mathrm{min}$.

As shown in Table 4.1, with the exception of the two Subsegment 2D samples, TGA results and oven drying at $105^{\circ} \mathrm{C}$ results give the same value of water content to within $3 \mathrm{wt} \%$ water. Oven drying typically provides higher water contents than TGA, probably due to the use of small (10 to $50 \mathrm{mg}$ ) high- . surface-area samples in the TGA that are exposed to flowing dry argon or nitrogen for up to a few minutes as the operator prepares to begin the analysis. 


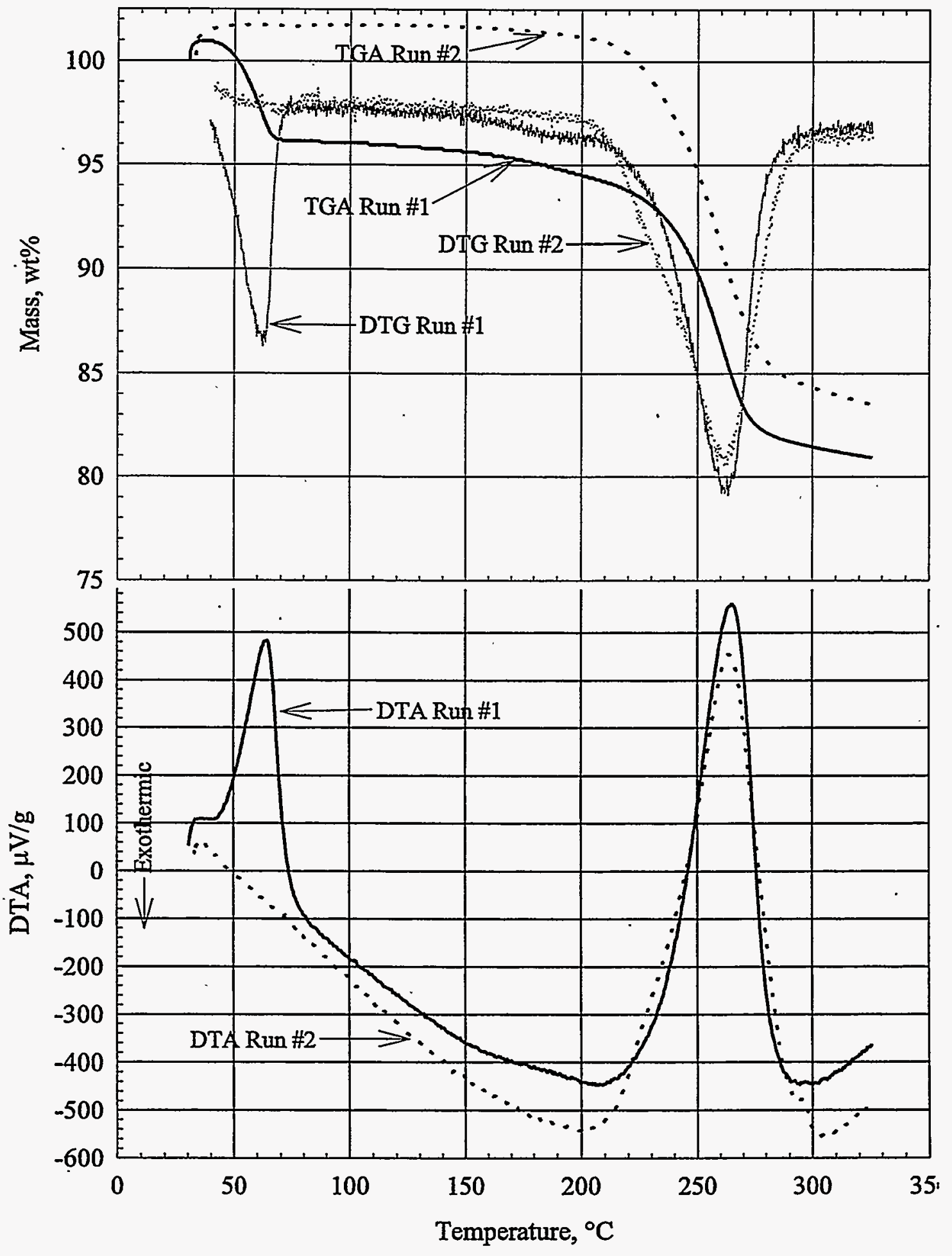

Figure 4.8. Thermal Behavior as Measured by TGA and DTA of Segment 1 Waste after Equilibrating with a $\mathrm{P}_{\mathrm{H} 2 \mathrm{O}}$ of 29 torr and Later with 2.2 torr and Dried at $105^{\circ} \mathrm{C}$. Segment 1 was obtained by Core 99 from BY-108 


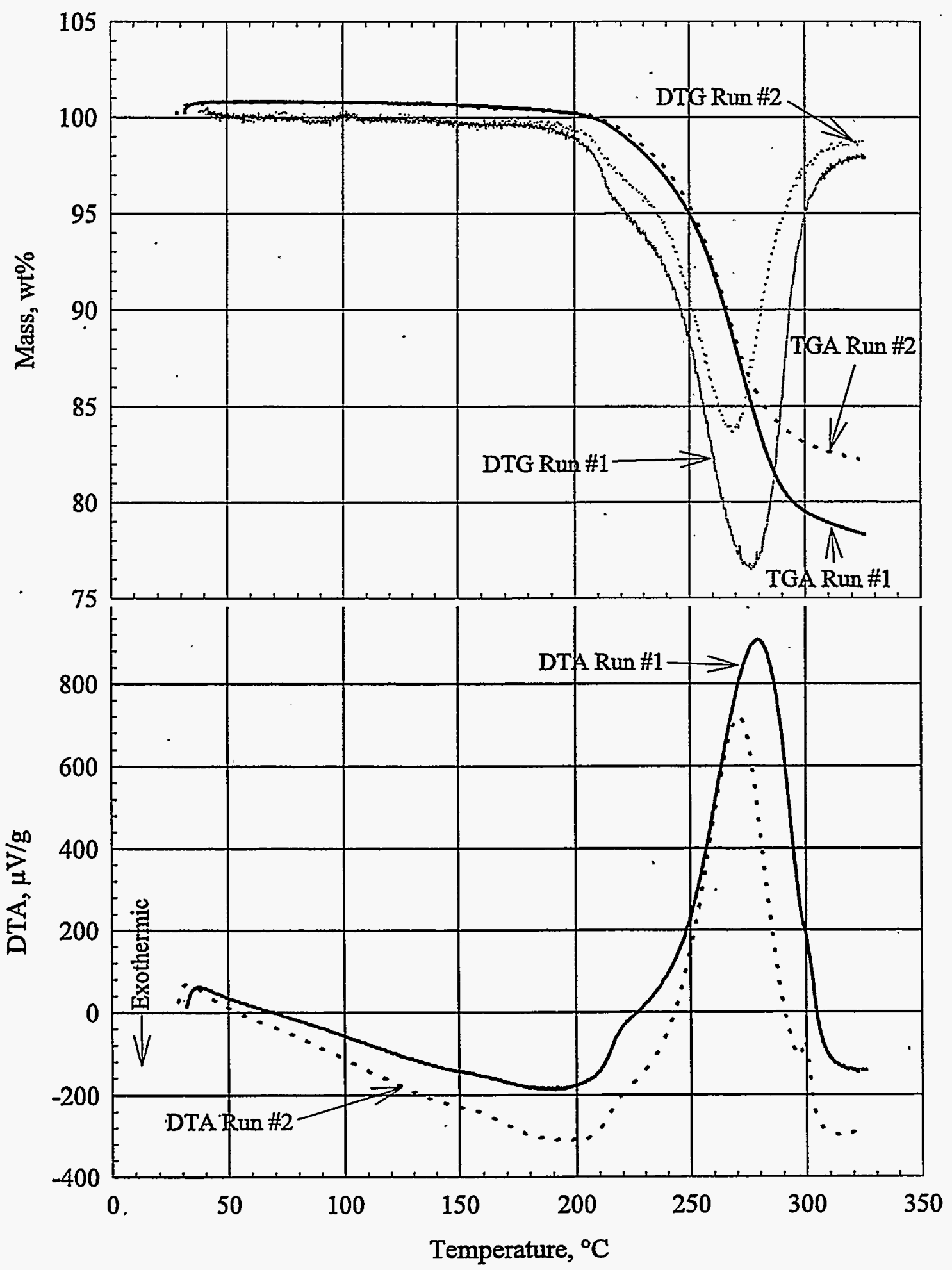

Figure 4.9. Thermal Behavior as Measured by TGA and DTA of Segment 1 Waste after Equilibrating with a $\mathrm{P}_{\mathrm{H} 2 \mathrm{O}}$ of 2.2 torr and Later with 29 torr and Dried at $105^{\circ} \mathrm{C}$. Segment 1 was obtained by Core 99 from BY-108 


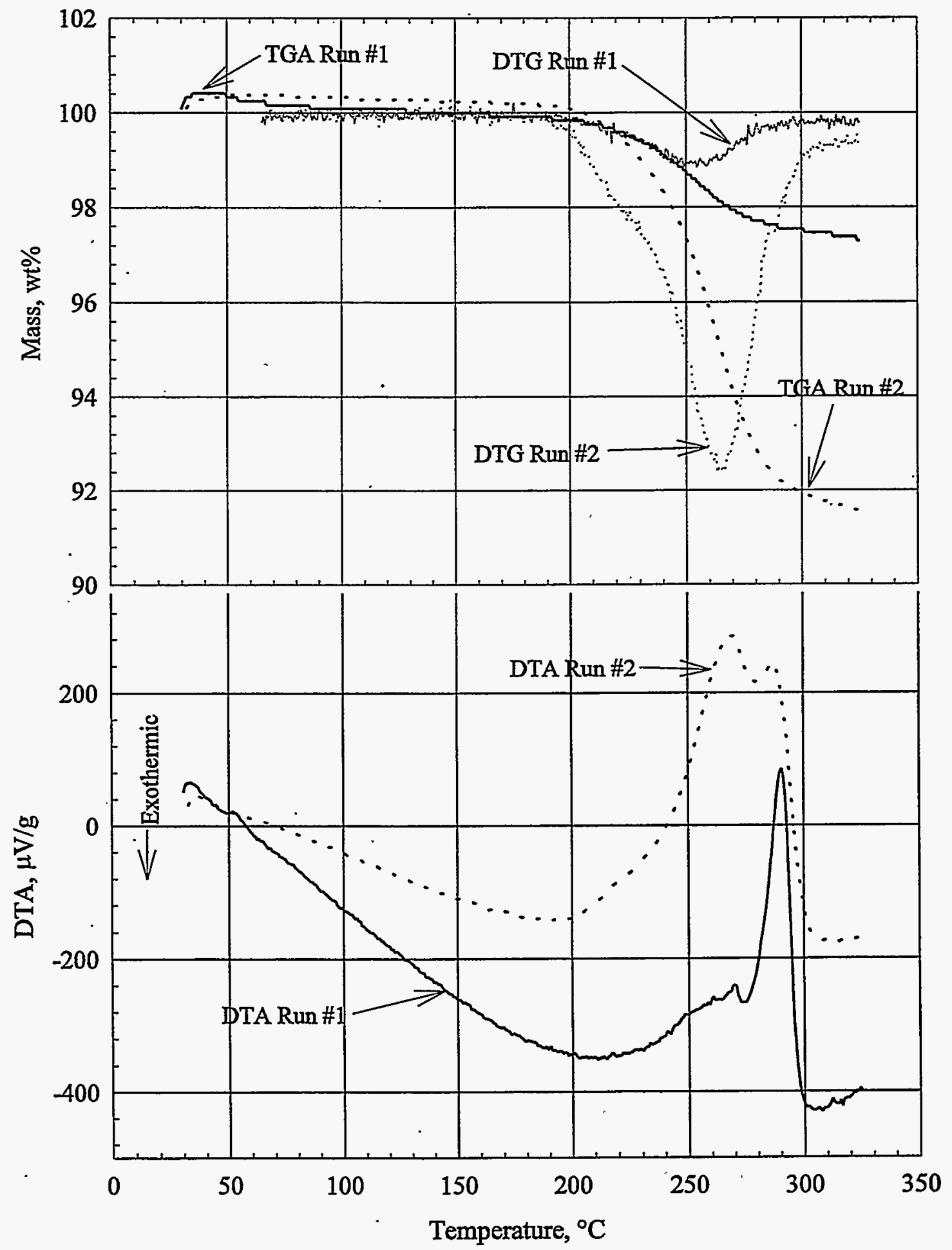

Figure 4.10. Thermal Behavior as Measured by TGA and DTA of Subsegment 2D Waste after Equilibrating with a $\mathrm{P}_{\mathrm{H} 20}$ of 29 torr and Later with 2.2 torr and Dried at $105^{\circ} \mathrm{C}$. Subsegment 2D was obtained by Core 99 from BY- 108 . 


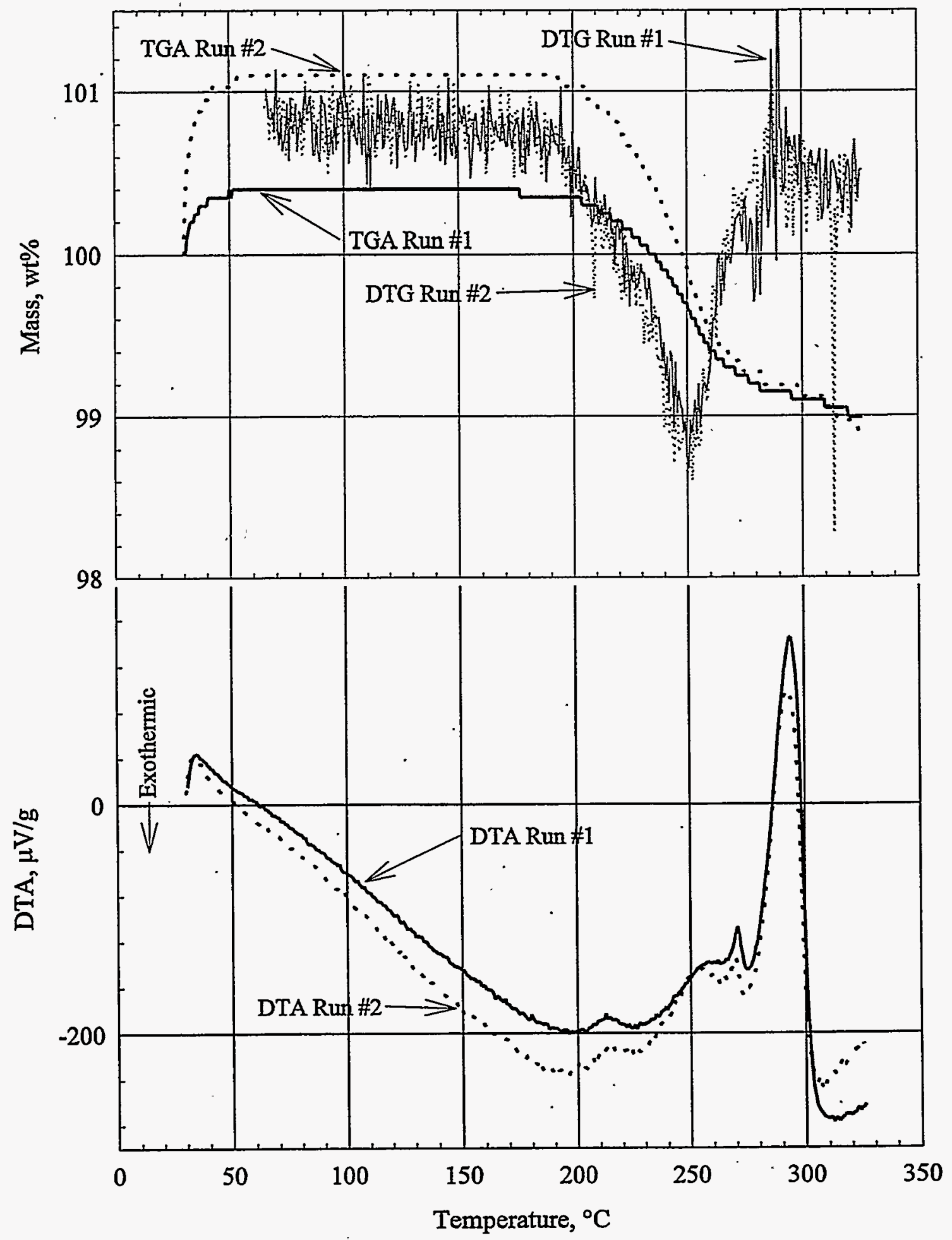

Figure 4.11. Thermal Behavior as Measured by TGA and DTA of Subsegment 2D Waste after Equilibrating with a $\mathrm{P}_{\mathrm{H} 2 \mathrm{O}}$ of 29 torr and Later with 2.2 torr, and Dried at $105^{\circ} \mathrm{C}$. Subsegment $2 \mathrm{D}$ was obtained by Core 99 from BY-108. 
Table 4.1. Water Content of Waste Obtained by Core 99 Segment 1 and Subsegment Equilibrated with 2.2 and 29 torr as Determined by Oven Drying at $105^{\circ} \mathrm{C}$ and TGA

\begin{tabular}{||c|c|c|c||}
\hline Segment & $\begin{array}{c}\text { Final } \\
\mathrm{P}_{\mathrm{H} 2 \mathrm{O}}, \text { torr }\end{array}$ & $\begin{array}{c}\text { Water Content by } \\
\text { Oven Drying, wt\% }\end{array}$ & $\begin{array}{c}\text { Water Content } \\
\text { by TGA, wt } \%\end{array}$ \\
\hline 1 & 29 & 45 & 48 \\
\hline 1 & 29 & 49 & 50 \\
\hline 1 & 2.2 & 6 & 6 \\
\hline 1 & 2.2 & 3 & 1.3 \\
\hline $2 \mathrm{D}$ & 29 & 68 & 54 \\
\hline $2 \mathrm{D}$ & 29 & 67 & 60 \\
\hline $2 \mathrm{D}$ & 2.2 & 2 & 0.8 \\
\hline $2 \mathrm{D}$ & 2.2 & 2 & 0.5 \\
\hline
\end{tabular}




\subsection{Conclusions}

Water content has been identified as one of the primary factors that will prevent propagating and selfsustaining hazardous reactions between organic fuels and the inorganic oxidants added to Hanford's highlevel radioactive wastes. Because of this importance, water concentration is a crucial element in the criteria developed to assess the safety status of Hanford's organic-bearing wastes and to determine how the wastes must be managed to maintain a minimum safety classification of Conditionally Safe.

Water partial pressure in the headspace is one of the principal factors that will control the water content in the stored waste by determining whether water is lost or gained by the waste. Low water partial pressures will dry the waste, and high water partial pressures will cause the waste to add water. How much water is lost or gained at a particular $\mathrm{P}_{\mathrm{H} 2 \mathrm{O}}$ depends on the strength of the chemical bonds between the waste and the water.

Duke Engineering and Services Hanford recognized that the arid Hanford environment with its relatively low water partial pressures could cause the water content in organic-bearing wastes to drop below acceptable levels (Webb et al. 1995) and commissioned PNNL to study the effect of $\mathrm{P}_{\mathrm{H} 2 \mathrm{O}}$ on the water content of Hanford organic-bearing wastes. The objectives of this study are to determine whether 1) ambient Hanford water partial pressures will cause the waste's water content to drop below acceptable levels, 2) active management of $\mathrm{P}_{\mathrm{H} 2 \mathrm{O}}$ is required to ensure an acceptable water content, and 3) control of $\mathrm{P}_{\mathrm{H} 2 \mathrm{O}}$ will provide a method to return a waste having a lower than acceptable water content to an acceptable level.

As part of this study, PNNL investigated the effect of $\mathrm{P}_{\mathrm{H} 2 \mathrm{O}}$ on the equilibrium water content of the characteristic saltcake waste samples taken by Core 99 from the uppermost segment (Segment 1) (upper $5 \mathrm{~cm}$ ) and a subsegment within $48 \mathrm{~cm}$ of the bottom of the top segment (Subsegment 2D) of the waste stored in BY-108. These studies using BY-108 waste found that, as expected, the equilibrium water content of these saltcake wastes depends on the $P_{H 2 O}$. Exposure to water partial pressures ranging from 2.2 to 29 torr resulted in water contents in the homogenized uppermost segment sample ranging from 1 to $48 \mathrm{wt} \%$ water within $1100 \mathrm{~h}$, respectively. Exposure of the homogenized Subsegment 2D sample to water partial pressures ranging from 2.2 to 29 torr resulted in water contents ranging from 1 to $62 \mathrm{wt} \%$ water within $500 \mathrm{~h}$.

In general, the BY-108 study indicates that in addition to the conclusion that saltcake does not constitute a singular waste classification with respect to water-retention properties, the equilibrium water content in saltcake wastes at $30^{\circ} \mathrm{C}$

- depends on the waste's chemical composition. Aluminum and phosphate appear to be the primary influence on water retention at water partial pressures less than 20 torr, and nitrate/nitrite appears to become dominant at water partial pressures greater than 20 torr

- can be achieved within 1 to 2 months for high-surface-area wastes 
- will be less than the $20 \mathrm{wt} \%$ water needed to guarantee that a propagating reaction cannot occur when exposed to ambient Hanford Site water partial pressures. This indicates that active management or water content monitoring may be required to maintain Conditionally Safe conditions depending on TOC or waste energetics (Webb et al. 1995)

- can possibly be controlled at levels satisfying Webb et al. (1995) Conditionally Safe criteria based on TOC or waste energetics by controlling $\mathrm{P}_{\mathrm{H} 2 \mathrm{O}}$

- can be rehydrated by controlling $\mathrm{P}_{\mathrm{H} 2 \mathrm{O}}$, thus providing a potentially effective means to mitigate an Unsafe (Webb et al. 1995) waste. 


\subsection{References}

Baldwin, J. H., R. J. Cash, L. Amato, and T. Tran. 1996. Tank Characterization Report for Single-Shell Tank 241-BY-108. WHC-SD-WM-ER-533, Westinghouse Hanford Company, Richland Washington.

Barney, G. S. 1976. Vapor-Liquid-Solid Phase Equilibria of Radioactive Sodium Salt Wastes àt Häford. ARH-ST-113, Atlantic Richfield Hanford Company, Richland, Washington.

Fauske, H. K., M. Epstein, D. R. Dickenson, R. J. Cash, and J. E. Meacham. 1995. The Contact Temperature Ignition (CTI) Criteria for Propagating Chemical Reactions Including the Effect of Moisture and Application to Hanford Waste. WHC-SD-WM-ER-496, Rev. 0, Westinghouse Hanford Company, Richland, Washington.

Hanlon, B. M. 1996. Waste Tank Summary Report for Month Ending September 30, 1996. WHC-EP0182-102, Westinghouse Hanford Company, Richland, Washington.

Lilga, M. A., M. R. Lumetta, W. F. Riemath, R. A. Romine, and G. F. Schiefelbein. 1992. Ferrocyanide Safety Project: Subtask 3.4 Ferrocyanide Aging Studies FY1992 Annual Report. PNNL-8387, Pacific Northwest Laboratory, Richland, Washington.

Lilga, M. A., M. R. Lumetta, and G. F. Schiefelbein. 1993. Ferrocyanide Safety Project: Task 3 Ferrocyanide Aging Studies FY1993 Annual Report. PNNL-8888, Pacific Northwest Laboratory, Richland, Washington.

Lilga, M. A., E. V. Alderson, D. J. Kowalski, M. R. Lumetta, and G. F. Schiefelbein. 1994: Ferrocyanide Safety Project: Task 3 Ferrocyanide Aging Studies FY1994 Annuial Report. PNNL-10126, Pacific Northwest Laboratory, Richland, Washington.

Lilga, M. A., R. T. Hallen, E. V. Alderson, M. O. Hogan, T. L. Hubler, G. L. Jones, D. J. Kowalski, M. R. Lumetta, W. F. Riemath, R. A. Romine, G. F. Schiefelbein, and T. E. Telander. 1996.

Ferrocyanide Safety Project Ferrocyanide Aging Studies Final Report. PNNL-11211, Pacific Northwest National Laboratory, Richland, Washington.

Pool, K. H., J. C. Evans, B. L. Thomas, K. B. Olsen, J. S. Fruchter, and K. L. Silvers. 1996. Headspace Vapor Characterization of Hanford Waste Tank 241-BY-108: Comparison Study Results from Samples Collected on 1/23/96". PNNL-11151, Pacific Northwest National Laboratory, Richland, Washington.

Scheele, R. D., P. R. Bredt, and R. L. Sell. 1996. Organic Tank Safety Project: Development of a Method to Measure the Equilibrium Water Content of Hanford Organic Tank Wastes and Demonstration of Method on Actual Waste. PNNL-11227, Pacific Northwest National Laboratory, Richland, Washington. 
Scheele, R. D., L. L. Burger, R. L. Sell, P. R. Bredt, and R. J. Barrington. 1994. Ferrocyanide Safety Project: Comparison of Actual and Simulated Ferrocyanide Waste Properties. PNNL-10175, Pacific Northwest Laboratory, Richland, Washington.

Scheele, R. D., J. L. Sobolik, R. L. Sell, and L. L. Burger. 1995. Organic Tank Safety Project: Preliminary Results of Energetics and Thermal Behavior Studies of Model Organic Nitrate and/or Nitrite Mixtures and a Simulated Organic Waste. PNL-10213, Pacific Northwest Laboratory, Richland, Washington.

Stedwell, M. J. 1954. Evaluation of Nickel Ferrocyanide Scavenging of Uranium Recovery Plant Solvent Extraction Waste. HW-31428, Hanford Atomic Works Operation, Richland, Washington.

Weast, R. C., M. J. Astle, and W. H. Beyer. 1984. CRC Handbook of Chemistry and Physics. CRC Press, Boca Raton, Florida.

Webb, A. B., J. L. Stewart, D. A. Turner, M. G. Plys, B. Malinovic, J. M. Grigsby, D. M. Camaioni, P. G. Heasler, W. D. Samuels, and J. J. Toth. 1995. Preliminary Safety Criteria for Organic Watch List Tanks at the Hanford Site. WHC-SD-WM-SARR-033 Rev 0, Westinghouse Hanford Company, Richland, Washington. 


\section{Distribution}

No. of

Copies

\section{OFFSITE}

2 DOE/Office of Scientific and Technical Information

S. F. Agnew

Los Alamos National Laboratory

P. O. Box 1663

Los Alamos, NM 87545

H. Babad

2540 Cordoba Court

Richland, WA 99352

K. K. Bandyopadhyay

Brookhaven National Laboratory

Upton, NY . 11973

D. Campbell

102 Windham Road

Oak Ridge, TN 37830

S. J. Eberlein

Westinghouse Savannah River Co. 241-121H

Aiken, SC 29802

M. Epstein

Fauske and Associates, Inc.

16 W070 W. 83rd St.

Burr Ridge, IL 60521

H. K. Fauske

Fauske and Associates, Inc.

16 W070 W. 83rd St.

Burr Ridge, IL 60521
No. of

Copies

B. C. Hudson

202 Northridge Court

Lindsborg, KA 67456

T. S. Kress

102-B Newridge Road

Oak Ridge, TN 37839

J. L. Kovach

Nuclear Consulting Services, Inc.

P. O. Box 29151

Columbus, OH 43229-0151

T. E. Larson

2711 Walnut Street

Los Alamos, NM 87544

D. A. Powers

MS-0744

Sandia National Laboratories

P.O. Box 5800

Albuquerque, NM 87185

S. E. Slezak

MS-0741

Sandia National Laboratories

P.O. Box 5800

Albuquerque, NM 87185

ONSITE

8 DOE Richland Operations Office
S. O. Branch
S7-54
R. E. Gerton
S7-54
W. F. Hendrickson
S7-54
D. H. Irby (2)
S7-54
$\mathrm{H} 2-53$
RL Docket File (2)

Distr.1 
No. of

Copies

FAI

M. G. Plys

H4-62

MACTEC

M. H. Campbell

S7-73

Los Alamos National Laboratory

J. R. White

K5-12

Babcock \& Wilcox Hanford Company

G. S. Barney

T5-12

Duke Engineering and Services Hanford

R. J. Cash

J. E. Meacham (2)

A. B. Webb

S7-14

S7-14

H4-65

Independent

J. M. Grigsby

L. M. Stock
H4-62

S7-14
No. of

Copies

Lockheed Martin Hanford Company
N. W. Kirch
R2-11
D. A. Reynolds
R2-11

45 Pacific Northwest National Laboratory

J. M. Bates

K7-15

P. R. Bredt (10)

P7-25

J. W. Brothers (2)

K5-22

S. A. Bryan

P7-25

L. L. Burger

P7-25

D. M. Camaioni

K2-38

C. D. Carlson

R. T. Hallen

W.D. Samuels

P7-25

P8-38

K2-44

K. D. Savard (2)

K9-04

P7-25

P7-25

R. L. Sell

C. S. Simmons

K9-33

C. W. Stewart

K7-15

J.M. Tingey

P7-25

J. J. Toth

K7-94

Organic Tank Project File (4)

P8-08 